JERZY ŁAZOR

https://orcid.org/0000-0002-8880-1085

Szkoła Główna Handlowa w Warszawie

\title{
„BROŃ DYPLOMATYCZNA PIERWSZEJ RANGI”? POWSTANIE POLSKO-FRANCUSKIEGO BANKU ŚLĄSKIEGO SA PO I WOJNIE ŚWIATOWEJ ${ }^{1}$
}

Zarys treści: W artykule przedstawiono proces powstawania Banku Ślaskiego SA w Katowicach po I wojnie światowej. Głównym celem jest analiza negocjacji prowadzonych przez Artura Benisa, a następnie Wacława Olszewicza z francuskimi dyplomatami i bankierami w latach 1920-1922. Autor wskazuje, że wbrew wcześniejszym interpretacjom Polacy byli istotnym podmiotem wpływającym na kierunek i rezultaty negocjacji związanych z przyszłościa gospodarczą Górnego Śląska. Niepowodzenie koncepcji utworzenia polsko-francuskiego banku na terytorium przyznanym Polsce tłumaczy niezdecydowaniem Francuzów i zmianą sytuacji gospodarczej w trakcie trwania negocjacji.

The content outline: The text outlines the process of creation of Bank Ślaski SA [Silesian Bank SA] in Katowice after World War I. The core of the article is the analysis of negotiations conducted between Artur Benis, and later Wacław Olszewicz, with French diplomats and bankers in 1920-1922. The author points out that previous interpretations of the talks mischaracterized the role of the Poles, who were in fact an important party influencing the direction and outcomes of the negotiations concerning the economic future of Upper Silesia. The failure of the concept of a Polish-French bank in the territory annexed by Poland is explained by the wavering attitude of the French and the changes in economic situation taking place during the period of negotiations.

${ }^{1}$ Serdecznie dziękuję koleżankom i kolegom z Katedry Historii Gospodarczej i Społecznej Szkoły Głównej Handlowej w Warszawie za dyskusję nad wstępną wersją tekstu. Szczególne wyrazy wdzięczności składam Cecylii Leszczyńskiej za obszerne i niezwykle przydatne uwagi do ostatecznej wersji artykułu. Badania zostały sfinansowane ze środków na prowadzenie badań naukowych lub prac rozwojowych oraz zadań z nimi związanych służących rozwojowi młodych naukowców oraz uczestników studiów doktoranckich w Kolegium Ekonomiczno-Społecznym Szkoły Głównej Handlowej w Warszawie. 
Słowa kluczowe: II Rzeczpospolita, Francja, Górny Śląsk, Artur Benis, Bank Ślaski SA, Skarboferm

Keywords: Second Polish Republic, France, Upper Silesia, Artur Benis, Bank Ślaski SA, Skarboferm

\section{Wstęp}

„Już pierwsza moja wizyta w banku i zapoznanie się z grubsza z jego stanem i interesami dało obraz po prostu przerażajacy. Administracja wysoce niechlujna, w buchalterii stan całkowitej mgławicy, kredytodawstwo nie pozostawiajace żadnych złudzeń co do sposobu traktowania interesów. [...] Bliższe wejrzenie [...] ujawniło zupełnie niesłychany stan rzeczy. Skłoniło mnie to do postawienia sprawy likwidacji banku, którego potrzeba gospodarcza również zresztą nie była do obronienia”"2. Tak w latach sześćdziesiątych wspominał swój pierwszy kontakt z Bankiem Ślaskim SA specjalista finansowy Banku Gospodarstwa Krajowego (BGK) Wacław Konderski. Sytuacja, której był świadkiem, niewiele miała wspólnego ani ze świetlaną przyszłościa, jaką wróżyli bankowi dyplomaci na początku lat dwudziestych, ani z próbą uczynienia z niego banku emisyjnego dla Górnego Ślaska.

Bank Ślaski SA z siedzibą w Katowicach był jedyną inwestycją w bankowość II Rzeczypospolitej, w która bezpośrednio zaangażowane były władze Francji. Powstał na mocy tajnego porozumienia podpisanego 29 XII 1921 r. przez polskiego delegata Artura Benisa i francuskiego premiera i ministra spraw zagranicznych Aristide’a Brianda. Stanowiło ono część pakietu umów z Francją dotyczących współpracy na terenie Górnego Śląska. Najważniejsza z nich doprowadziła do utworzenia Skarbofermu, polsko-francuskiego konsorcjum zarządzającego dawnymi pruskimi kopalniami skarbowymi, które przez znaczna część dwudziestolecia międzywojennego było największym eksporterem polskiego węgla.

Proces powstawania Banku Ślaskiego był bardziej skomplikowany niż utworzenie Skarbofermu. Rozmowy trwały cały rok 1921, na skutek różnych komplikacji jego powołanie przeciągnęło się aż do sierpnia 1922 r. Celem niniejszego artykułu jest zbadanie tego procesu i powiazanie go z dalszymi losami banku.

Tradycyjnie niepowodzenie działalności tej instytucji tłumaczy się niewielkim zainteresowaniem sfer gospodarczych Francji oraz inflacja

${ }^{2}$ W. Konderski, $Z$ działalności banków polskich w latach 1928-1935: wspomnienia, Warszawa 1962, s. 71. 
marki niemieckiej. W tekście pokazuję, że przyczyny były szersze. Przede wszystkim utrudnieniem $\mathrm{w}$ funkcjonowaniu banku były rozwiązania techniczne przyjęte $\mathrm{w}$ trakcie jego tworzenia $\mathrm{z}$ powodów politycznych, mimo zaangażowania francuskich instytucji finansowych w drugiej połowie 1922 r. Po drugie, badajac przebieg negocjacji, pokazuję dynamikę relacji między władzami III Republiki a jej sferami finansowymi, odrzucając stare tezy polskiej historiografii o znacznym wpływie tych drugich. Z analizy dokumentów wyłania się obraz banku, który został powołany bez wyraźnego celu gospodarczego, a którego forma była wynikiem ścierania się różnych grup interesów.

Negocjacje, które doprowadziły do powstania Banku Śląskiego, sa w ogólnych zarysach znane polskiej historiografii. Pierwsza pracę na ten temat, silnie nacechowaną ideologicznie, opublikował Franciszek Ryszka ${ }^{3}$. Podstawą dla późniejszych badań jest zbiór źródeł do historii misji Artura Benisa wydany przez Zbigniewa Landaua i Jerzego Tomaszewskiego ${ }^{4}$. Między innymi na tych materiałach oparł się Józef Kukułka, który opisał relacje polsko-francuskie w okresie 1919-1922 , a także sam Landau badający pożyczki zaciagnięte po I wojnie światowej przez Polskę ${ }^{6}$. O misji Benisa pisał również obszernie Zenon Szmidtke w swojej monografii Skarbofermu ${ }^{7}$. Dalsze losy Banku Ślaskiego SA nie są dobrze znane, podobnie jak historia większości prywatnych instytucji kredytowych w okresie międzywojennym ${ }^{8}$. Najwięcej o śląskiej bankowości pisze Mariusz Trąba ${ }^{9}$, a cytowany już Wacław Konderski opisuje likwidację Banku Śląskiego ${ }^{10}$.

W literaturze francuskiej o powstaniu banku pisali Georges-Henri Soutou $^{11}$ i, w nieopublikowanym doktoracie, Christophe Laforest ${ }^{12}$.

${ }^{3}$ F. Ryszka, Kulisy decyzji w sprawie Ślaska w r. 1921, KH, t. 60, 1953, nr 1, s. 127-167.

${ }^{4}$ Z. Landau, J. Tomaszewski, Misja prof. A. Benisa, „Teki Archiwalne” 6, 1959, s. $29-225$.

5 J. Kukułka, Francja a Polska po traktacie wersalskim: 1919-1922, Warszawa 1970.

${ }^{6}$ Z. Landau, Polskie zagraniczne pożyczki państwowe 1918-1926, Warszawa 1961.

7 Z. Szmidtke, „Skarboferm” 1922-1939: zwiazki polityki z gospodarka, Opole 2005.

8 Por. W. Morawski, Stownik historyczny bankowości polskiej do 1939 roku, Warszawa 1998, s. 137-138; A. Gasiorski, Bank Handlowy w Warszawie S.A. Oddziat $w$ Częstochowie 1897-1997. Historia oddziału banku na tle instytucji finansowych regionu, Częstochowa 1997.

${ }^{9}$ M. Trąba, Bankowość, w: Województwo ślaskie (1922-1939). Zarys monograficzny, red. F. Serafin, Katowice 1996, s. 365-390.

${ }_{10}$ W. Konderski, dz. cyt.

11 G.-H. Soutou, La politique économique de la France en Pologne (1920-1924), „Revue historique” 251, 1974, nr 1, s. 85-116.

${ }^{12}$ Ch. Laforest, La stratégie française et la Pologne (1919-1939). Aspects économiques et implications politiques, Paris 2001, mps pracy doktorskiej, Université Paris 1 Panthéon-Sorbonne. 
Wpisują oni dzieje tej instytucji w szerszą politykę Francji wobec Polski, wskazując na jej imperialny kontekst. Opracowanie Laforesta jest obszerniejsze i opiera się na szerokiej podstawie źródłowej, obaj autorzy nie znali jednak polskich materiałów. Z polskiej literatury korzystała z kolei Mylène Mihout-Natar w swojej również nieopublikowanej dysertacji ${ }^{13}$, jej praca nie wnosi jednak wiele do historiografii banku.

Niniejsze opracowanie stanowi rozwinięcie istniejącej literatury w trzech obszarach. Jako pierwsze w kompleksowy sposób pokazuje okoliczności powstania Banku Śląskiego. Ponadto podnosi nieznane dotychczas w literaturze wątki dotyczące mechanizmów podejmowania decyzji finansowych oraz interakcji między sfera publiczną i prywatna w relacjach polsko-francuskich. Wreszcie daje nowa, bardziej pozytywną interpretację części efektów misji Artura Benisa.

Podstawą źródłowa pracy sa - z polskiej perspektywy - wspomniane dokumenty wydane przez Landaua i Tomaszewskiego. Francuską wersję wydarzeń reprezentują materiały archiwalne zgromadzone w Archives Diplomatiques w La Courneuve (materiały Ministère des Affaires Étrangères, MAÉ) oraz Centre des Archives Économiques et Financières w Savigny-le-Temple (materiały Ministère des Finances, MF). Te drugie bywają niełatwe $\mathrm{w}$ interpretacji, gdyż zawierają wiele niedatowanych, niepodpisanych i niepaginowanych kopii bądź minut listów i notatek.

Artykuł składa się z czterech części oraz zakończenia. W pierwszych trzech częściach przedstawiam kolejne etapy negocjacji w podziale chronologicznym: do wybuchu III powstania ślasskiego, do podpisania porozumienia w grudniu 1921 r., wreszcie do utworzeniu banku i pierwszych miesięcy jego działalności. W ostatniej części badam strony biorące udział w rozmowach, określając ich wewnętrzne podziały oraz przyjęta taktykę. W zakończeniu, poza podsumowaniem rozważań, wskazuję też kierunki dalszych badań.

\section{Koncepcja banku polsko-francuskiego na Górnym Śląsku}

Traktat wersalski dawał państwom alianckim, do których dzięki zabiegom dyplomatycznym zaliczono też Polskę, prawo do przymusowego wykupu na swoim terytorium własności należącej do obywateli

${ }^{13}$ M. Mihout-Natar, L’intervention des capitaux français dans la Pologne de la Seconde République (1918-1939). Contribution à l'histoire de l'impérialisme économique français en Europe centrale, Lille 2002, mps pracy doktorskiej, Université Charles de Gaulle - Lille III. 
niemieckich (art. 297) ${ }^{14}$. Z tej perspektywy niezwykle ważne były dalsze losy Górnego Ślaska. Gdyby prowincja ta przypadła w wyniku plebiscytu Polsce, nowe państwo miałoby prawo wykupić znajdujące się tam potężne zakłady przemysłowe, przejęłoby też majątek państwa niemieckiego, zwłaszcza zaś kopalnie skarbowe. Ponieważ ostateczna decyzja o losach Górnego Ślaska zależała od wielkich mocarstw, Polska próbowała pozyskać ich poparcie, oferując koncesje na terenie prowincji „niejako za łapówkę”, jak ują to naczelnik Wydziału Północnego Stanisław Koźmiński podczas konferencji naczelników wydziałów politycznych MSZ 16 XI 1920 r. $^{15}$

Prowadzenie rozmów z wielkimi mocarstwami powierzono profesorowi Uniwersytetu Jagiellońskiego, prawnikowi i ekonomiście Arturowi Benisowi. Wkrótce okazało się, że polską oferta nie były zainteresowane ani Włochy, ani Anglia, rozmowy prowadzono jedynie z Francja. W starszej polskiej historiografii pojawiał się - wywodzący się jeszcze z dwudziestolecia - zarzut o bezsensowności oferowania koncesji Francji, która i bez tego popierała przekazanie Polsce Ślaska ${ }^{16}$. Zarzut ten, niepozbawiony słuszności, nie uwzględnia jednak drugiego aspektu działalności Benisa: w przypadku otrzymania Górnego Śląska Polska i tak musiałaby szukać zewnętrznego finansowania na wykup niemieckich przedsiębiorstw. Propozycje Benisa dawały szanse na długofalowe związanie Francji z losami polskiego Górnego Śląska.

Wizja współpracy z mocarstwami na terytorium ślaskim obejmowała również sferę bankowa. Z protokołu wspomnianej konferencji wynika, że powstanie banku miało przede wszystkim rozwiązać problem niedostatku dewiz koniecznych w kontaktach z Górnym Ślaskiem, gdzie wciąż obowiązywała niemiecka waluta. Mówił o tym kierownik Wydziału Ekonomicznego MSZ Wacław Olszewicz: „Niemcy swoje kapitały wycofuja, my resztę marek niemieckich wydajemy na węgiel śląski, pozostaje więc tylko stworzenie międzynarodowej instytucji bankowej z udziałem kapitałów obcych, koalicyjnych i neutralnych oraz niemieckich"17.

Benis zderzył się jednak z brakiem zainteresowania ze strony Francuzów, dlatego koncepcja banku ewoluowała. Najpierw jako „Międzynarodowy Bank Śląski”18 miał się on stać jednym ze źródeł zysków, którymi kuszeni byli rozmówcy Benisa ${ }^{19}$. Przedstawiany był jako korzystna

\footnotetext{
${ }^{14}$ F. Ryszka, dz. cyt., s. 130-131.

15 Z. Landau, J. Tomaszewski, dz. cyt., 1, s. 37; Z. Landau, dz. cyt., s. 101.

16 Z. Landau, J. Tomaszewski, dz. cyt., 1, s. 29; tamże, 3, s. 172.

17 Tamże, 1, s. 36.

18 Tamże, 3, s. 40

19 Tamże, 5, s. 46
} 
inwestycja dla sprzymierzonych kapitałów, która opierałaby się na eksploatacji „pewnych bardzo poważnych przywilejów” ${ }^{20}$. W połowie grudnia 1920 r. jego powstanie uzasadniano dodatkowo koniecznością dostarczenia kapitałów obrotowych firmom, które powstałyby na terenie Górnego Ślaska, zapewnienia obsługi finansowej Zagłębia oraz „ewentualny[m] odkup[em] prywatnego przemysłu niemieckiego (akcje, udziały etc.)"21.

Francuzi wciąż nie byli przekonani do tej koncepcji ${ }^{22}$. W związku z tym na początku 1921 r. z nazwy banku znikną komponent „międzynarodowy"23, a z uzasadnienia jego tworzenia - motyw zysku. Banque de Haute-Silésie (Bank Górnośląski) - pod taką nazwą funkcjonował bowiem w negocjacjach - miał służyć głównie do obsługi finansowej polsko-francuskich inwestycji; Benis przekonywał, że był on ich koniecznym uzupełnieniem, co Francuzi przyjmowali z pewna niechęcią ${ }^{24}$. Bank miał dać polsko-francuskim firmom niezależność od niemieckiego finansowania na Górnym Śląsku, a jego istnienie zwolniłoby Warszawę z konieczności zaopatrywania ich $\mathrm{w}$ marki niemieckie. W argumentacji wracał więc pierwotny, „walutowy” charakter działalności banku. Maxime Vicaire, francuski specjalista od polskich spraw gospodarczych, w liście z połowy stycznia pisał, że według Polaków znaczenie banku było jeszcze większe. Miałby on być głównym dostawca kapitału dla przemysłu górnośląskiego oraz realizować wielką akcję wykupu niemieckich przedsiębiorstw przez francuski i polski kapitał. Pojawiła się nawet koncepcja przejęcia około sześćdziesięciu oddziałów wielkich niemieckich banków. Wedle polskich rozmówców Vicaire’a wymagałoby to kapitału rzędu 500 mln marek ${ }^{25}$.

Wstępną wizję przyszłego banku Benis przedstawił na spotkaniu polskich i francuskich ekspertów u zastępcy kierownika Dyrekcji Spraw

20 Tamże, 7, s. 50.

${ }^{21}$ Tamże, s. 52; tekst francuski noty Benisa: Archives Diplomatiques (dalej: AD), Correspondance politique et commercial, 1918-1940, Pologne (dalej: PL 1918-1940), 212, Mémoire de M. Arthur Benis, Délégué Plénipotentiaire du Gouvernement polonais pour les affaires économiques de la Haute Silésie, 17 XII 1920 r., k. 48v.

${ }^{22} \mathrm{Na}$ przykład Charles Laurent, ambasador w Berlinie, nazwał ja nadmiernie skomplikowana, nie rozumiał też polskiej propozycji udziału Wielkiej Brytanii, której interesy na Górnym Ślassu były zasadniczo odmienne od polskich; AD, PL 1918-1940, 212, [Ch. Laurent do MAÉ], 24 XII 1920 r., k. 50.

${ }^{23}$ G.-H. Soutou, dz. cyt., s. 110.

${ }^{24}$ Z. Landau, J. Tomaszewski, dz. cyt., 13, s. 52; AD, PL 1918-1940, 212, Participation française aux affaires de Haute-Silésie. Point de vue français, 5 II $1921 \mathrm{r}$., k. 107-108; tamże, 220, Entretien de M. Laroche avec M. Bénis, 9 II 1921 r., k. 1-2.

${ }^{25}$ AD, PL 1918-1940, 212, M. Vicaire do F. François-Marsala, 11 I 1921 r., k. 59. 
Politycznych i Handlowych MAÉ Jules'a Laroche'a, 15 II 1921 r. ${ }^{26}$ Kilka dni później zaproponował ogólne zasady funkcjonowania instytucji: siedziba na Górnym Ślasku, a w rezultacie działanie na mocy ślaskiego prawa; kapitał zakładowy w wysokości 100-200 mln marek niemieckich, w połowie pochodzący z pożyczki francuskiej udzielonej na zasadach ustalonych rok wcześniej w konwencji Klotz-Olszowski. Bank Górnośląski miał przez 10 lat być oficjalnym przedstawicielem Polskiej Krajowej Kasy Pożyczkowej (PKKP) i móc liczyć na uprzywilejowane traktowanie przez polskie władze ${ }^{27}$. Sam bank powinien - poza obsługa przejmowania firm niemieckich - zapewnić ciagłość działalności przemysłowej na Górnym Ślasku.

Wspomniana konwencja została podpisana 17 stycznia 1920 r. przez francuskiego ministra finansów Louisa-Luciena Klotza i przedstawiciela polskiego MSZ Kazimierza Olszowskiego ${ }^{28}$. Stanowiła ramowy układ określający zasady udzielania Polsce kredytów na odkup przedsiębiorstw niemieckich ${ }^{29}$. Prawną podstawę jej realizacji rząd w Paryżu otrzymał od parlamentu rok później, 28 II 1921 r. Uzyskał wówczas prawo do dysponowania znajdującą się w posiadaniu Skarbu francuskiego znaczna ilością marek kupionych po korzystnym kursie w Alzacji i Lotaryngii ${ }^{30}$.

Wbrew temu, co pisał Benis w swoim raporcie ${ }^{31}$, rząd francuski zają raczej stanowisko wyczekujące niż negatywne, a urzędnicy zaczęli badać opłacalność polskich propozycji. W notatce MAÉ stwierdzono wówczas, że z perspektywy francuskich wpływów utworzenie takiego banku mogłoby być korzystne, choć przedstawiciel Ministerstwa Finansów nie chciał, aby wykorzystano do tego fundusze uruchomione w ramach konwencji Klotz-Olszowski ${ }^{32}$. W Dyrekcji Obrotu Pieniężnego (Direction du Mouvement

${ }^{26}$ Tamże, 220, Participation française aux affaires de Haute-Silésie, 15 II 1921 r., k. 7-10.

27 Tamże, Principes du statut de la Banque de Haute Silésie, 19 II 1921 r., k. 11-12; tamże, Project d'un accord concernant la création de la Banque de Haute Silésie, 19 II 1921 r., k. 12-13.

28 Z. Landau, J. Tomaszewski, dz. cyt., 1, s. 162-168; Convention de marks signée à Paris entre MM. L.L. Klotz et Casimir Olszowski, Paris 17 janvier 1920, w: Documents diplomatiques français, 1920, t. 1, red. J. Bariéty, Paris 1997, s. 31-35.

${ }^{29}$ M. Mihout-Natar, dz. cyt., s. 119-121.

${ }^{30}$ Centre des Archives Économiques et Financières (dalej: CAÉF), Direction du Trésor. Relations internationales - Pologne 1919-1939 (dalej: DT PL 1919-1939), B 31.942, Ch. de Lasteyrie, R. Milliès-Lacroix, 27 IV 1922 r., bpag.; AD, PL 1918-1940, 212, Notatka „Collaboration économique franco-polonaise en Haute Silésie”, 15 XII 1923 r., k. 311-312v.

${ }^{31}$ Z. Landau, J. Tomaszewski, dz. cyt., 17, s. 70.

32 AD, PL 1918-1940, 212, Notatka „Affaires économiques de Haute-Silésie”, 18 II 1921 r., k. 135. 
Général des Fonds), kluczowej instytucji ulokowanej przy Ministerstwie Finansów, odpowiedzialnej m.in. za zarządzanie funduszami skarbowymi i obsługe długu publicznego, 21 II $1921 \mathrm{r}$. zorganizowano w tej sprawie spotkanie z przedstawicielami francuskich banków prywatnych. Misję wstępnego zbadania zagadnienia, a także rozeznania możliwości pozyskania kapitałów francuskich prywatnych instytucji finansowych powierzono Bankowi Francusko-Polskiemu w Paryżu ${ }^{33}$, którego prezesem był senator Joseph Noulens ${ }^{34}$. W koncepcji władz francuskich udział obydwu rządów dałby bankowi silna pozycję, a przekazanie Ślaska Polsce gwarantowałoby podstawy dla dobrej działalności - tak w formie depozytów, jak i obsługi strumieni kapitału zwiąanych z przemysłem górnoślasskim. Jednocześnie wysokość kapitału koniecznego do spełniania przez bank tak zdefiniowanych jego funkcji wiązano z przewidywanym tempem opuszczania Górnego Ślaska przez kapitał niemiecki. Uznano, że wobec prawdopodobnego powolnego charakteru tego procesu projektowana instytucja nie musiała od razu uzyskać całego kapitału $200 \mathrm{mln}$ marek niemieckich, czyli 40 mln franków ${ }^{35}$.

W marcu 1921 r. okazało się jednak, że banki francuskie nie chciały angażować się finansowo w Bank Górnoślasski bez gwarancji francuskiego rządu. Stały za tym dwa czynniki. Po pierwsze, same znajdowały się w trudnej sytuacji. Po drugie, ich właściciele obawiali się inwestować w Polsce wobec niepewności jej dalszych losów. Nadchodzący plebiscyt na Górnym Śląsku niepewność tę tylko potęgował. W konsekwencji władze banków deklarowały możliwości zainwestowania kwoty $50 \mathrm{mln}$ marek niemieckich, czyli o połowę mniejszej niż przewidywały polskie projekty ${ }^{36}$.

Postawa banków spowodowała sformułowanie celów wobec Banku Górnośląskiego przez Quai d'Orsay. Po pierwsze, stwierdzono, że zaangażowanie $\mathrm{w}$ ten projekt miałoby charakter bardziej polityczny niż gospodarczy. Po drugie, również kontekst ekonomiczny interpretowano politycznie. Argumentowano, że jeśli Francja nie wspomoże Polski, jej miejsce zajmą wspominani przez stronę polską w negocjacjach Hiszpanie

${ }^{33}$ Banque Franco-Polonaise, stworzony w 1920 r. przez duże banki paryskie w celu obsługi wymiany między Francją a Polską i Wolnym Miastem Gdańsk; Ch. Laforest, dz. cyt., s. 271-279; W. Morawski, Bankowość prywatna w II Rzeczypospolitej, Warszawa 1996, s. 33-34.

${ }^{34}$ G.-H. Soutou, dz. cyt., s. 111.

${ }^{35}$ AD, PL 1918-1940, 220, Notatka MAÉ, 7 III 1921 r., k. 15-18.

${ }_{36}$ Tamże, Notatka MAÉ, 15 III 1921 r., k. 22-24; por. Z. Landau, J. Tomaszewski, dz. cyt., 34, s. 111. Prawdopodobnie z tego okresu pochodzi porzucony projekt porozumienia francusko-polskiego (CAÉF, DT PL 1919-1939, B 31.942, Projekt porozumienia w sprawie utworzenia Banku Górnośląskiego, [III 1921 r.?], bpag.), zgodnie z którym Bank Górnośląski miałby zastapić funkcjonujące na Górnym Śląsku banki niemieckie. 
i Włosi, a za nimi - wedle Quai d’Orsay - z pewnością kryć się będa Niemcy. W rezultacie uważano, że należy możliwie szybko związać Polaków umowa ${ }^{37}$. Można mieć wątpliwości co do realności spełnienia się francuskich obaw, skoro Włosi jeszcze w 1919 r. nie byli zainteresowani wstępnymi propozycjami Benisa ${ }^{38}$.

Nieco inne stanowisko zajmowali urzędnicy Ministerstwa Finansów. W notatce przygotowanej dla kierującego wspomniana Dyrekcją Obrotu Pieniężnego Jeana Parmentiera, stwierdzono, że marki, którymi dysponował rząd francuski, lepiej byłoby przeznaczyć na wykup istniejacych niemieckich przedsiębiorstw. Autor notatki ubolewał jednak, że Polacy uznawali wykup za niemożliwy bez utworzenia banku i dowodził, że ten powinni finansować prywatni finansiści francuscy i polscy, bez udziału władz centralnych ${ }^{39}$.

W rozmowach, które miały miejsce w drugiej połowie marca w MAÉ i siedzibie Banku Francusko-Polskiego, Francuzi starali się wymusić na Benisie ustępstwa w kilku obszarach ${ }^{40}$. Głównym postulatem było prawo Banku Górnośląskiego do reprezentowania PKKP na terenie Górnego Ślaska przez 15 lat od jego powstania. Oczekiwano zagwarantowania mu szerokiego zakresu działalności, w tym uznania przez polskie władze za bank państwowy w polskiej części Górnego Ślaska, z prawem emisji waluty, która zastapiłaby markę niemiecka. Bank miałby też pośredniczyć w wykupie niemieckich przedsiębiorstw. Francuzi byli zaniepokojeni słowami Benisa, który rolę banku ograniczał do obsługi Skarbofermu, a inne sfery działalności określił jako „teoretyczne"41, starali się zatem uzyskać gwarancję, że bank będzie uczestniczyć we wszystkich gospodarczych działaniach rządu polskiego na Górnym Ślasku wymagajacych wsparcia finansowego. Strona francuska oczekiwała także ograniczenia konkurencji ze strony polskich banków, w związku z tym wskazywała, że możliwie wiele z nich powinno partycypować w zakładaniu projektowanej instytucji finansowej. Oczekiwania te, zwłaszcza realizacja prawa do emisji pieniądza oraz reprezentowania PKKP, oznaczałyby istotne uszczuplenie polskiej suwerenności gospodarczej na Górnym Ślasku. Miały one na celu zachęcenie

${ }^{37}$ AD, PL 1918-1940, 220, Notatka MAÉ, 15 III 1921 r., k. 22-24.

38 Z. Landau, dz. cyt., s. 102-103.

39 CAÉF, DT PL 1919-1939, B 31.942, Notatka Direction du Mouvement général des Fonds dla J. Parmentiera, 20 III 1921 r., bpag.

40 AD, PL 1918-1940, 220, Notatka MAÉ, 15 III 1921 r., k. 22-24; tamże, Notatka MAÉ, 17 III 1921 r., k. 25-27; tamże, Participation française aux affaires de Haute-Silésie, 18 III 1921 r., k. 29-30; tamże, Notatka MAÉ, 24 III 1921 r., k. 38-41.

${ }^{41}$ Tamże, Notatka MAÉ, 17 III 1921 r., k. 25-27. 
francuskich banków do włączenia się do inwestycji; te ponoć w prawie do emisji widziały un grand intérêt ${ }^{42}$.

Choć Benis miał niewielkie możliwości manewru - powstanie banku zależało wyłącznie od dobrej woli Francuzów, którzy mieli zapewnić nowej instytucji cały potrzebny kapitał - to jego sprzeciw wobec wspomnianych żądań był silny. Nie zgodził się na przyznanie bankowi prawa do emisji ${ }^{43}$, argumentował też, że o wykorzystaniu nowej instytucji jako banku Skarbu ślaskiego musi zadecydować przyszły Sejm Ślaski (co nie przekonało Francuzów, uważali oni bowiem, że o takich zagadnieniach decyduje rząd). W sprawie reprezentacji PKKP był gotów zgodzić się jedynie na zagwarantowanie 10 , a nie 15 lat.

Równolegle Benis wystapił z żądaniem udzielenia kolejnej pożyczki francuskiej w wysokości $200 \mathrm{mln}$ marek, tym razem na kapitał obrotowy banku ${ }^{44}$. To ciekawy moment negocjacji, kiedy szczególnie wyraźnie ujawniła się różnica stanowisk między sferami gospodarczymi Francji a jej władzami. Prywatne banki ochoczo przychyliły się do polskiego żądania, gdyż widziały w nim możliwość uzyskania dodatkowego wsparcia dzięki subwencjom Paryża, które spłacać musiałby polski rząd. Argumentowano, że bez wpłaty tego kapitału działalność banku nie będzie mogła się rozpoczaćc. Reakcja rządu francuskiego była wymijająca. Jules Laroche, rozmawiając z Benisem w imieniu MAÉ, powołał się na rozbieżności między Quai d’Orsay a resortem finansów. Stwierdził, że trudno będzie liczyć na zgodę na nowa, tak wysoką pożyczkę i konieczne będzie zapewnienie bankowi uprzywilejowanej pozycji w celu skompensowania ryzyka.

Taki przebieg negocjacji, w którym Quai d’Orsay było głównym motorem starań o utworzenie Banku Górnośląskiego, każe podać w wątpliwość wywiedzione z polskich materiałów archiwalnych tezy Józefa Kukułki o uzależnieniu francuskiego rządu od sfer finansowych ${ }^{45}$ (nie mówiąc już o argumentach Franciszka Ryszki, dla którego rząd ten był „na usługach kapitału"46). Bliższe omawianym tu dokumentom są oceny Jacques'a

${ }^{42}$ Tamże, k. 25.

${ }^{43}$ Ch. Laforest, dz. cyt., s. 280.

${ }_{44}$ Z. Landau, J. Tomaszewski, dz. cyt., 17, s. 70; we francuskiej notatce pochodzącej prawdopodobnie z przełomu 1921 i 1922 r. wysokość tego kredytu została początkowo określona na poziomie $300 \mathrm{mln}$ franków, a następnie kwotę tę poprawiono na $100 \mathrm{mln}$, za: CAÉF, DT PL 1919-1939, B 31.942, Notatka „Banque de Haute-Silesie”, bpag.; por. tamże, Avenant à la convention du 17 janvier 1920 concernant l'emploi et les conditions du remboursement des sommes destinées à la Banque de Haute Silésie, 19 II 1921 r., bpag.

45 J. Kukułka, dz. cyt., s. 339.

${ }^{46}$ F. Ryszka, dz. cyt., s. 143. 
Bariéty'ego, który na podstawie badań stosunków francusko-niemieckich stwierdził, że sfery gospodarcze miały ograniczony wpływ na działalność Quai d'Orsay, a w zakresie polityki bezpieczeństwa to raczej one stanowiły instrument polityki rządowej ${ }^{47}$. Dodać można, że w przypadku Polski instrument raczej mało powolny, sprawiający znaczne trudności.

Dalsze rozmowy prowadzono na podstawie protokołu wyznaczajacego ogólne zręby przyszłego statutu banku, sporządzonego przez Benisa na żądanie banków francuskich ${ }^{48}$. Ich efektem był przygotowany w połowie $1921 \mathrm{r}$. kwietnia projekt porozumienia ${ }^{49}$. Uzasadniało ono decyzję o utworzeniu banku chęcia polskiego i francuskiego rządu zapewnienia pomyślnego rozwoju gospodarczego Górnego Ślaska. Projekt zakładał kapitał początkowy w wysokości $200 \mathrm{mln}$ marek, w innych aspektach status banku miał być zgodny z oczekiwaniami Francuzów. Zgodzono się na gwarancję jego udziału we wszystkich przedsiębiorstwach przemysłowych utworzonych na Górnym Ślasku przez polski rząd z udziałem kapitału prywatnego. Najdłużej negocjowano kwestię relacji Banku Górnośląskiego z PKKP. Benis nie godził się, aby był on jedynym przedstawicielem Kasy na Górnym Ślasku oraz by ta nie mogła na obszarze jego działania otwierać swoich oddziałów. Wobec nacisków Francuzów skonsultował to z rządem polskim ${ }^{50}$. Ostatecznie dano bankowi prawo reprezentowania Kasy i innych banków państwowych przez 15 lat. Ukłonem w stronę Polaków było prawo PKKP do utworzenia na terenie Górnego Ślasku jednego oddziału ${ }^{51}$. Polacy nie zgodzili się natomiast na nadanie nowej instytucji przywileju emisji. Istotnym novum była zgoda Polski na ewentualną cesję części akcji francuskich na rzecz Amerykanów lub Belgów ${ }^{52}$, przy czym $75 \%$ akcji w posiadaniu obydwu grup było zblokowane i nie można było ich sprzedawać, scedować albo w innych sposób alienować

${ }^{47}$ J. Bariéty, Industriels allemands et industriels français à l'époque de la République de Weimar, „Revue d'Allemagne et des pays de langue allemande” 4, 1974, nr 2, s. $1-16$.

${ }^{48}$ AD, PL 1918-1940, 220, Projets de formules pour une convention sur la Banque de Haute-Silésie, 24 III 1921 r., k. 42-47, tamże, Notatka MAÉ, 24 III 1921 r., k. 41; pierwotna wersja protokołu i jego dalsze ewolucje, generalnie na niekorzyść Polski, znajdują się w CAÉF, DT PL 1919-1939, B 31.942.

49 AD, PL 1918-1940, 220, Projekt porozumienia w sprawie Banku Górnośląskiego, 16 IV 1921 r., k. 54-57; por. Z. Landau, J. Tomaszewski, dz. cyt., 25, s. 84-88.

${ }^{50}$ AD, PL 1918-1940, 220, Dwie notatki „Participation française aux affaires de Haute-Silésie", 25 III 1921 r., k. 48-51.

${ }_{51}$ Tamże, A. Benis do J. Laroche'a, 11 IV 1921 r., k. 52-53.

${ }_{52}$ Tamże, Projets de formules pour une convention sur la Banque de Haute-Silésie, 24 III 1921 r., k. 42-47. 
bez porozumienia obu stron. $\mathrm{Z}$ dokumentów nie wynika, komu bardziej zależało na tym zapisie, choć można przypuszczać, że stały za tym prywatne banki francuskie, szukające możliwości zmniejszenia własnego zaangażowania $\mathrm{w}$ przedsięwzięcie.

Powodzenie rozmów nie zdało się na wiele. W lutym Benis pisał, że zgoda w sprawie banku to kwestia dni ${ }^{53}$, w Polsce myślano o organizowaniu polskich akcjonariuszy ${ }^{54}$, tymczasem w wewnętrznej notatce z 30 kwietnia urzędnicy MAÉ stwierdzili, że choć rząd polski naciska na szybkie przekazanie kapitału, banki francuskie nie sa na to gotowe. Wynikało to głównie z nieufności tak do polskiego systemu gospodarczego, jak i polskiej „dobrej wiary” ${ }^{55}$. W szczególności niepewnością napawała przyszłość finansowa Górnego Śląska - czy utrzymaja się tam marki niemieckie, czy zostana przestemplowane, wreszcie czy Polacy wprowadzą własną walutę. Francuzom przeszkadzało, że zgodnie ze statutem organicznym województwa ślaskiego ${ }^{56}$ Ślask nie będzie miał pełnej autonomii w kwestiach pieniężnych ${ }^{57}$. Stanowisko to potwierdza, że Francuzi starali się zminimalizować polski wpływ na nowa prowincję. Dwa dni po powstaniu tej notatki na Górnym Ślasku wybuchło trzecie powstanie.

\section{Droga do porozumienia polsko-francuskiego}

Do rozmów w sprawie powołania banku wrócono jesienia 1921 r., w nowej sytuacji politycznej, po zaakceptowaniu przez Radę Ambasadorów korzystnej dla Polski decyzji Międzysojuszniczej Komisji Rządzącej i Plebiscytowej o podziale Górnego Ślaska. Na podstawie nowego upoważnienia do kontynuowania rozmów z Francuzami ${ }^{58}$, na początku listopada 1921 r. Artur Benis odwiedził MAÉ i przedstawił memorandum przypominające wcześniejsze ustalenia. Stało się ono podstawą do dalszych rozmów ${ }^{59}$.

53 Z. Landau, J. Tomaszewski, dz. cyt., 18, s. 71.

54 Tamże, 21, s. 77.

${ }_{55}$ AD, PL 1918-1940, 220, Notatka MAÉ „Banque de Haute Silésie”, 30 IV 1921 r., k. 61 (tłumaczenia cytatów źródłowych J.Ł.); por. tamże, 212, Note sur les accords franco-polonais relatifs aux exploitations minières de Haute-Silésie, 5 VIII 1921 r., k. 191.

${ }^{56}$ Ustawa Konstytucyjna z dnia 15 lipca 1920 r. zawierajacca statut organiczny Województwa Ślaskiego, Dz. U. 1920, nr 73 poz. 497.

57 Francuzi jednak błędnie interpretowali zasady statutu organicznego, myląc kwestie pieniężne ze skarbowymi; AD, PL 1918-1940, 220, Notatka MAÉ „Banque de Haute Silésie", 30 IV 1921 r., k. 61.

58 Z. Landau, J. Tomaszewski, dz. cyt., 28, s. 93-94.

${ }_{59}$ AD, PL 1918-1940, 220, A. Benis, Aide-mémoire au sujet de la Banque Franco-Polonaise en Haute-Silésie, 12 XI 1921 r., k. 66-69. 
Na przebieg negocjacji wpływ miały czynniki zewnętrzne. Pierwszym, paradoksalnie wzmacniającym polską pozycję, były zbliżające się rozmowy polsko-niemieckie przewidziane w genewskiej decyzji o podziale Górnego Ślasska ${ }^{60}$. Benis informował Francuzów, że od decyzji w sprawie banku zależały instrukcje dla polskich negocjatorów ${ }^{61}$. Drugim czynnikiem były zmiany w warunkach gospodarowania na Górnym Ślasku. Francuzi wskazywali, że genewska decyzja o 15-letniej ochronie Niemców przed wywłaszczeniem oznaczać może ich utrzymanie na czele spółek na Ślasku, co źle rokowało przejęciu przez bank klienteli na terenie prowincji. Większym problemem były kwestie finansowe. Niemiecka inflacja oznaczała spadek wartości realnej planowanego kapitału zakładowego ${ }^{62}$, a decyzja genewska pozostawiająca markę niemiecka jako walutę na Górnym Śląsku na 15 lat oddzielała jego rynek od polskiego. Konieczne było też porozumienie z Reichsbankiem w sprawie ewentualnego redyskonta weksli ${ }^{63}$. Benis przekonywał Francuzów, że problemy te nie maja istotnego wpływu na koncepcje przyjęte w kwietniu, a nawet tym bardziej wymuszają utworzenie banku w prowincji odciętej od niemieckiego banku centralnego ${ }^{64}$. Briand był gotów się z nim zgodzić, uznając utworzenie banku za jedno z wielu działań Francuzów na Górnym Śląsku. Po raz pierwszy użył też nowego argumentu: skoro w prowincji panował niemiecki model bankowości, wyrażający się dużym zaangażowaniem instytucji finansowych w działalność przemysłową i inwestycyjna, utworzenie banku z kapitałem francuskim i polskim było konieczne, aby otrzymać odpowiednia pozycję inwestorów znad Sekwany i Wisły w górnośląskim biznesie i podważyć pozycję banków niemieckich ${ }^{65}$.

W łonie rządu francuskiego rozpoczęła się dyskusja nad polskimi propozycjami i dalszymi losami banku (poza MAÉ i MF włączono do niej również Ministerstwo Terenów Wyzwolonych ${ }^{66}$ ). Stwierdzono, że należy włączyć się w tworzenie banku, bo nie można zostawić Niemcom przewagi w postaci obsługi bankowej wszystkich firm na polskim Górnym

${ }^{60}$ K.J. Błahut, Polsko-niemieckie stosunki gospodarcze w latach 1919-1939, Wrocław 1975, s. 58-59.

${ }^{61}$ AD, PL 1918-1940, 220, A. Benis, Aide-mémoire au sujet de la Banque Franco-Polonaise en Haute-Silésie, 12 XI 1921 r., k. 66-69.

${ }^{62}$ Tamże, Notatka MAÉ „Banque de Haute Silésie”, 9 XI 1921 r., k. 62-62v.

${ }^{63}$ CAÉF, DT PL 1919-1939, B 31.942, Niedatowana notatka o redyskoncie weksli, prawdopodobnie z przełomu 1921 i 1922 r., z adnotacja „Maxime Vicaire”, bpag.

${ }^{64}$ AD, PL 1918-1940, 220, A. Benis, Aide-mémoire au sujet de la Banque Franco-Polonaise en Haute-Silésie, 12 XI 1921 r., k. 66-69.

65 Tamże, A. Briand do P. Doumera, 17 XI 1921 r., k. 70-72; tamże, A. Briand do P. Doumera, 18 XI 1921 r., k. 76-77.

66 Tamże, L. Loucheur do A. Brianda, 23 XI 1921 r., k. 83. 
Śląsku. Obawiano się, że z braku gwarancji Polacy zwrócą się do inwestorów z innych państw - Włoch, Austrii czy Anglii - co będzie skutkowało utratą francuskich wpływów ${ }^{67}$. Ponownie podniesiono zatem argumenty natury politycznej.

Francuskie władze wróciły do formowania grupy prywatnych inwestorów. Wytypowano szereg banków i przedsiębiorstw przemysłowych jako potencjalnych inwestorów i rozpoczęto z nimi rozmowy ${ }^{68}$. Początkowo gotowość zgłaszał Banque de Paris et des Pays-Bas, na tym etapie jednak jego przedstawiciel wycofał się, przekazując pałeczkę Banque de l'Union Parisienne. Prezes tego banku z kolei poinformował MF, że z racji niepewności kursu marki niemieckiej bezpośredni udział grupy francuskich instytucji finansowych nie będzie możliwy bez przekazania przez rząd kwoty 100 mln marek niemieckich (z ewentualna gwarancja ze strony polskiej ${ }^{69}$ ). To przesuwałoby odpowiedzialność za finansowanie banku na Ministerstwo Finansów ${ }^{70}$. Na przełomie listopada i grudnia 1921 r. doszło do impasu - Francuzi rozważali różne propozycje (jak zaproszenie do udziału Amerykanów) i kolejno je odrzucali. Przedstawiciele banków chcieli, aby wyznaczono przewodniczącego grupy francuskiej, który pokierowałby procesem, ale nikt nie chciał się tego podjaćc ${ }^{71}$.

Wobec zbliżającego się terminu negocjacji polsko-niemieckich ponaglane przez Artura Benisa i Józefa Wielowieyskiego władze francuskie zdecydowały się podpisać porozumienie możliwie szybko, nawet bez zapewnienia udziału banków. Miało to dać Polakom „broń dyplomatyczna pierwszej rangi" ${ }^{2}$, efektem były zaś poprawki do projektu porozumienia z kwietnia $1921 \mathrm{r}$. (w większości techniczne, choć należy zanotować wykreślenie art. 15, który określał, jak miały być

${ }^{67}$ Tamże, Notatka MAÉ „Création d'une banque franco-polonaise de Haute Silésie”, 21 XI 1921 r., k. 81-81v.

${ }^{68}$ CAÉF, DT PL 1919-1939, B 31.942, Note pour Monsieur Noulens, [XII 1921?], bpag.

69 Tamże, Projet d'une formule de garantie concernant la Banque de la Haute-Silésie, 7 XII 1921 r., bpag.

70 AD, PL 1918-1940, 220, Notatka MAÉ „Aide-mémoire concernant la Banque de la Haute-Silésie”, 24 XI 1921 r., k. 84-85; CAÉF, DT PL 1919-1939, B 31.942, Notatka „Création d'une banque franco-polonaise en Haute-Silésie”, bpag.; szerzej o postawie banków zob. Ch. Laforest, dz. cyt., s. 281.

${ }^{71}$ AD, PL 1918-1940, 220, Notatka MAÉ „État des négociations relatives à la constitution de la Banque de Haute Silésie”, 8 XII 1921 r., k. 86; tamże, Notatka MAÉ „Banque de Haute-Silésie. État des pourparlers relatifs à la constitution”, 16 XII 1921 r., k. 87-87v.

${ }_{72}$ Tamże, Notatka MAÉ dla A. Brianda, „Convention franco-polonaise relative à la constitution de la Banque de Haute-Silésie”, 23 XII 1921 r., k. 88b; por. CAÉF, DT PL 1919-1939, B 31.942, P. Doumer do A. Brianda, 20[?] XII 1921 r., bpag. 
wykorzystane zyski z działalności banku ${ }^{73}$. W dramatycznej notatce z 27 grudnia urzędnik MAÉ stwierdzał, że jakkolwiek Francuzi nie byli gotowi gospodarczo do stworzenia banku, musieli podpisać porozumienie, aby ułatwić negocjatorom polskim uniknięcie niemieckich nacisków: ,jeśli porozumienie nie zostanie natychmiast podpisane, Niemcy będą mogli narzucić swoja pozycję. [...] Będziemy pracować dla Prus"74. Innymi słowy Józef Kukułka mylił się, pisząc na podstawie polskich źródeł, że rządowi francuskiemu udało się w grudniu zebrać kapitał akcyjny potrzebny do stworzenia nowej instytucji ${ }^{75}$.

Efektem było podpisanie 29 XII 1921 r. w Paryżu przez Brianda i Benisa tajnej konwencji w sprawie utworzenia Banku Górnoślaskiego ${ }^{76}$. Miała one treść bliską kwietniowemu projektowi, choć w preambule nie uzasadniano już tworzenia banku dbałością o pomyślny rozwój gospodarczy Ślaska ${ }^{77}$. Szczególnie interesujacy z perspektywy gwarancji dla francuskich inwestorów był zapis potwierdzający reprezentowanie przez bank PKKP przez 15 lat oraz gwarantujący mu udziały w przyszłych polskich inwestycjach na Górnym Ślasku ${ }^{78}$.

\section{Proces tworzenia Banku Śląskiego SA w Katowicach}

Samo podpisanie konwencji było aktem politycznym, który nie przybliżał do rozwiazzania problemów finansowych i organizacyjnych. Do rozmów włączył się wówczas nowy aktor - generał Henri Le Rond, przewodniczacy Międzysojuszniczej Komisji Rządzącej i Plebiscytowej na Górnym Ślasku. Jego stanowisko było pragmatyczne, twierdził, że nowa instytucja powinna zaczaćc działać od momentu przekazania terytorium Polsce, co wymuszało przyspieszenie technicznych przygotowań, jak zakup budynków czy zatrudnienie ludzi ${ }^{79}$.

W Paryżu tego typu rady niewiele pomagały. Wciąż nie ustalono, które banki zainwestują w nową instytucję ani też, ile wyniesie ich

${ }^{73}$ AD, PL 1918-1940, 220, Projekt „Convention entre la France et la Pologne au sujet de la constitution de la Banque de Haute-Silésie”, [XII 1921], k. 89-92.

${ }_{74}$ Tamże, Note sur la Banque de Haute-Silésie, 27 XII 1921 r., k. 93-93v.

75 J. Kukułka, dz. cyt., s. 466.

${ }^{76}$ Stąd informacja Franciszka Ryszki, powtarzana następnie w historiografii, jest nieprawdziwa; F. Ryszka, dz. cyt., s. 151.

77 AD, PL 1918-1940, 220, Convention entre la France et la Pologne au sujet de la constitution de la Banque de Haute-Silésie, 29 XII 1921 r., k. 94-98.

${ }^{78}$ G.-H. Soutou, dz. cyt., s. 112.

79 AD, PL 1918-1940, 220, H. Le Rond do A. Brianda, 4 I 1922 r., k. 99. 
wkład. Tymczasem Polacy ponaglali, oczekując stanowiska Francuzów w sprawie organizacji finansowej Górnego Śląska najpóźniej do 15 stycznia i deklarując, że jego brak zmusi stronę polską do przyjęcia niemieckich propozycji współpracy ${ }^{80}$. Równolegle Darmstädterbank zaproponował kooperację na terenie Górnego Ślaska Bankowi Handlowemu w Warszawie i wspólne utworzenie nowej instytucji finansowej. Propozycja ta wydała się Polakom korzystna, co pokazywało istniejąca lukę w sektorze bankowym Górnego Ślasska ${ }^{81}$. Warto dodać, że Bank Handlowy w Warszawie był zgodnie z art. 2 konwencji Klotz-Olszowski reprezentantem rządu polskiego we wszelkich sprawach dotyczących wynikających z niej operacji.

Francuski punkt widzenia szczególnie dobitnie ukazał poseł w Warszawie Hector André de Panafieu, pisząc: „Byłoby godnym potępienia, gdyby nasze instytucje finansowe zaniedbały tę wyjątkową okazję, aby za kilka milionów franków pozyskać kontrolę gospodarczą nad Górnym Ślasskiem i, w rezultacie, nad całością ziem polskich. Z drugiej strony, nie będziemy mieli żadnych podstaw, aby protestować przeciw współpracy polsko-niemieckiej, jeśli za protestami nie będą szły [opuszczenie w oryg. - J.Ł.] francuskie" 82 . Jego słowa potwierdził w telegramie Briand, dodając, że „utrata korzyści” byłaby godna pożałowania, „zwłaszcza po tylu trudnościach z ustaleniem granicy [polsko-niemieckiej - J.Ł.]"83. Trwające w Paryżu rozmowy z inwestorami szły opornie, choć MF udało się znaleźć koordynatora negocjacji z prywatnymi bankami. Został nim Albert de Monplanet, prezes Crédit Industriel et Commercial, nobliwego banku francuskiego, działającego na arenie międzynarodowej, który stał się kluczowym inwestorem w nowej instytucji.

Od 15 stycznia premierem, a zarazem ministrem spraw zagranicznych Francji został Raymond Poincaré. Tekę ministra finansów obją Charles de Lasteyrie, bankier i deputowany z departamentu Corrèze. Również po stronie polskiej doszło do zmiany osób odpowiedzialnych za negocjacje: dalsze rozmowy na temat stworzenia grupy francuskiej powierzono MSZ (prowadził je Wacław Olszewicz, naczelnik Wydziału Ekonomicznego Ministerstwa), kwestię uczestnictwa polskich banków w przedsięwzięciu przejęło zaś Ministerstwo Skarbu ${ }^{84}$.

W okresie tym pojawiła się koncepcja senatora Josepha Noulensa, by zamiast Banku Górnoślasskiego powołać na Śląsku oddział Banku

\footnotetext{
80 Tamże, Ręczna notatka MAÉ, 8 I 1922 r., k. 101.

81 Z. Landau, J. Tomaszewski, dz. cyt., 33, s. 99.

82 AD, PL 1918-1940, 220, H.A. de Panafieu do MAÉ, 8 I 1922 r., k. 102.

${ }^{83}$ Tamże, A. Briand do MAÉ, 11 I 1922 r., k. 103.

${ }^{84}$ Z. Landau, J. Tomaszewski, dz. cyt., 34, s. 112.
} 
Francusko-Polskiego w Paryżu. Jak komentowano w MAÉ, bank ten traktował przyszły Bank Górnoślasski jak potencjalnego konkurenta ${ }^{85}$. Kiedy rząd Francji nie okazał zainteresowania tym projektem, a misję tworzenia nowej instytucji powierzono Albertowi de Monplanet, Noulens odmówił udziału w tej inicjatywie ${ }^{86}$. Co więcej, zaczął publicznie głosić, że Bank Francusko-Polski otworzy oddział na Górnym Ślasku, a do Polski udał się jego przedstawiciel ${ }^{87}$. Sytuacja ta skłoniła de Monplaneta do wycofania się z akcji powołania Banku Górnoślaskiego. Stwierdził on, że nie wyobraża sobie prowadzenia dalszych rozmów i uzależnił swoje zaangażowanie od stanowiska francuskich władz ${ }^{88}$. Smaku sprawie dodaje fakt, że Crédit Industriel et Commercial, którego prezesem był de Monplanet, był jednym z głównych udziałowców Banku Francusko-Polskiego ${ }^{89}$. Francuski rząd staną po stronie Banku Górnoślaskiego ${ }^{90}$. De Monplanet został ponownie poproszony o kierowanie grupa francuska i pod koniec lutego 1922 r. wrócił do rozmów z Francuzami i Polakami ${ }^{91}$.

Pozornie powyższy konflikt był zatem burzą w szklance wody, niemniej wymusił na nowych francuskich władzach określenie stanowiska w dyskusji na temat przyszłości i celów Banku Górnośląskiego. Poincaré $\mathrm{w}$ piśmie do Lasteyriego tłumaczył, że bank powstaje w jednym, konkretnym celu - dostarczania marek dla kopalni skarbowych i innych wielkich przedsiębiorstw kontrolowanych przez państwo w polskiej części Górnego Ślaska. Obydwaj zgodzili się, że nie mogło być zatem mowy o jakiejkolwiek monopolizacji francuskiej działalności bankowej na Ślasku przez Bank Górnoślasski ${ }^{92}$. Nowa interpretacja władz oznaczała zawężenie pierwotnej wizji banku, który miał dać Francuzom gospodarczą

${ }^{85}$ AD, PL 1918-1940, 220, Notatka MAÉ, 17 II 1922 r., k. 129-129b; Ch. Laforest, dz. cyt., s. 281-284.

${ }^{86}$ CAÉF, DT PL 1919-1939, Minuta „Note sur la création d”une banque en Haute-Silésie", niedatowana, bpag. Ostateczny dokument nosi datę 13 I 1922 r. i przywoływany jest w następnym przypisie; tamże, J. Parmentier, Note sur la création d'une banque en Haute Silésie, 15 II 1922 r., bpag.

${ }^{87}$ AD, PL 1918-1940, 220, Note sure la création d'une banque franco-polonaise en Haute-Silésie, 13 I 1922 r., k. 104-106; tamże, H. Le Rond do MAÉ, 19 II 1922 r., k. 133; tamże, H. Le Rond do R. Poincarégo, 8 II 1922 r., k. 121-122.

88 Tamże, MAÉ do H. Le Ronda, 17 II 1922 r., k. 130-130v.

${ }^{89}$ Ch. Laforest, dz. cyt., s. 284-285.

90 AD, PL 1918-1940, 220, MAÉ do H. Le Ronda, 21 II 1922 r., k. 142; G.-H. Soutou, dz. cyt., s. 113.

91 AD, PL 1918-1940, 220, H. Le Rond do MAÉ, 19 II 1922 r., k. 134-135; tamże, R. Poincaré do Ch. de Lasteyrie, 20 II 1922 r., k. 141-141b; tamże, Ch. de Lasteyrie do A. de Monplanet, Paris, 20 II 1922 r., k. 145-145v.

92 Tamże, R. Poincaré do Ch. de Lasteyrie, 20 II 1922 r., k. 141-141b; tamże, Ch. de Lasteyrie do A. de Monplanet, Paris, 20 II 1922 r., k. 145-145v. 
kontrolę nad Śląskiem. O zmianie zadecydowały dwa czynniki: aktywność Noulensa oraz utrzymanie marki niemieckiej na terytorium Górnego Śląska, które przenosiło ciężar obsługi prowincji na barki niemieckich banków prywatnych. W połączeniu z inflacją oznaczało to nikłe możliwości szerszego oddziaływania planowanego Banku Górnośląskiego.

W marcu 1922 r. do Francji wyjechał Wacław Olszewicz i przedstawiciele polskich banków. Po serii rozmów z Albertem de Monplanet Olszewicz udał się wraz z radca handlowym polskiego poselstwa Franciszkiem Doleżalem do Jules'a Laroche'a w MAÉ. Ustalono, że z racji spadku wartości marki konieczne będzie podniesienie kapitału akcyjnego banku z 200 to 250 mln marek. Skoro polski udział miał wynosić połowę, czyli $125 \mathrm{mln}$ marek, a nowo powstały Skarboferm miał dostarczyć 10 mln marek z tej kwoty, oznaczało to konieczność zwiększenia wysokości pożyczki francuskiej ze 100 do 115 mln marek, co z kolei wymagało wprowadzenia poprawki do porozumienia z grudnia $1921 \mathrm{r}^{93}$ Rząd francuski ogłosił zgodę na zwiększenie kapitału w połowie kwietnia. W następnych tygodniach sfinalizowano skład grupy francuskiej i polskiej (zob. załącznik 1 i 2) i przygotowano statut banku, który skonsultowano ze ślaskimi prawnikami (bank miał powstać na podstawie prawa obowiązującego w prowincji). Statut był rozwinięciem zasad zawartych w porozumieniu z 29 XII 1921 r. Wyróżniały się w nim liczne zapisy gwarantujace utrzymanie równości udziałów polskich i francuskich akcjonariuszy. Bank uzyskał ostatecznie nazwę Bank Ślaski SA / Banque de Silésie $\mathrm{SA}^{94} .1$ maja w siedzibie Crédit Industriel et Commercial odbyło się zebranie grupy francuskiej, na którym zdecydowano się powierzyć stanowisko dyrektora generalnego banku Maximowi Vicaire'owi, wówczas attaché handlowemu w Poselstwie Francji w Warszawie (jego kandydaturę wcześniej potwierdził francuski rząd) ${ }^{95}$.

Równolegle prowadzone negocjacje polsko-niemieckie zakończyły się podpisaniem $15 \mathrm{~V} 1922$ r. polsko-niemieckiej konwencji górnoślaskiej. W kwestii bankowości gwarantowała ona szereg przywilejów oddziałom największych banków niemieckich, które miały pozostać na terenie prowincji. Jednocześnie zobowiazywała te banki do zapewnienia odpowiedniej obsługi kredytowej przedsiębiorstw Górnego Ślasska ${ }^{96}$. Rozwiązywało

93 Tamże, Notatka „Visite de M. [W.] Olszewicz à M. [J.] Laroche”, 20 III 1922 r., k. 164-164b; tamże, Ch. de Lasteyrie do R. Poincarégo, 3 IV 1922 r., nr 3122, k. 171-171v.

${ }_{94}$ Tamże, Statuts de la Banque par actions: Bank Ślaski/Banque de Silésie, k. 179-191.

${ }^{95}$ CAÉF, DTPL 1919-1939, B 31.942, L. Dior do Ch. de Lasteyrie, 15 IV 1922 r., bpag.; AD, PL 1918-1940, 220, A. de Monplanet do R. Poincarégo, 28 VI 1922 r., k. 177-178v. ${ }^{96}$ Za: M. Traba, dz. cyt., s. 365-366. 
to problem ciagłości obsługi finansowej prowincji, jednocześnie potencjalnie zmniejszając rolę przyszłego Banku Śląskiego.

W tym momencie ujawnił się problem dotyczacy wskazania prezesa banku. Jeszcze w marcu 1922 r. Le Rond donosił, że według „plotek” miał nim zostać Wojciech Korfanty. Kandydaturę tę zasugerował też w czasie rozmów Olszewicz ${ }^{97}$. Korfanty wcześniej został wybrany na przewodniczącego Rady Nadzorczej Skarbofermu, co nie obyło się bez protestów w Polsce. Wedle Le Ronda wybór Korfantego byłby niekorzystny, ponieważ „Francja pozyskała na niego wpływ, którego nie ma na innych" polskich polityków i nie powinno się go narażać na utratę pozycji w Polsce ${ }^{98}$. Korfanty został mimo to wytypowany na prezesa, ale jego rola w polskiej polityce doprowadziła do kolejnego opóźnienia w powstaniu banku. Gdy desygnowano go na premiera podczas przesilenia gabinetowego w lipcu 1922 r., Francuzi zdecydowali się poczekać aż sprawa premierostwa się rozwiąże. Ostatecznie wobec sprzeciwu Piłsudskiego kandydaturę Korfantego na szefa rządu wycofano, a on sam został prezesem Banku Ślaskiego.

Pod koniec czerwca pojawiły się wątpliwości Francuzów dotyczące zapisów statutu banku, który gwarantowały rządom „pewien wgląd” w jego działalność, a także możliwość odrzucenia kandydatów do Rady Nadzorczej, jeśli wymagałby tego interes narodowy (mogłoby to sugerować, że bank nie jest samodzielny, a w rezultacie zniechęcić jego potencjalnych klientów) ${ }^{99}$. W notatce MAÉ dla Poincarégo podkreślano konieczność szybkiego podjęcia decyzji w tej sprawie, bo dalsze opóźnienia mogły całkiem pozbawić wartości marki niemieckie, które przeznaczono na utworzenie banku ${ }^{100}$. Ostatecznie przyjęto zapis, że swoista kontrolę nad bankiem w imieniu rządów obu państw będą sprawować wskazani członkowie Rady Nadzorczej banku, którzy mieli informować rządy o jego działalności. Ze strony francuskiej był to Henri Thélier, dyrektor Crédit Industriel et Commercial (pełniący też funkcje w kilku innych firmach). Jego odpowiednikiem po stronie polskiej został Artur Benis ${ }^{101}$.

${ }_{97}$ AD, PL 1918-1940, 220,, Notatka MAÉ dla J. Laroche'a, 27 III 1922 r., k. 169bis-169 bis v.

98 Tamże, H. Le Rond do MAÉ, 24 III 1922 r., k. 169.

99 Z. Landau, J. Tomaszewski, dz. cyt., 42, s. 131; AD, PL 1918-1940, 220, R. Poincaré do Ch. de Lasteyrie, 8 VII 1922 r., k. 207-208; tamże, A. de Monplanet do R. Poincarégo, 13 VII 1922 r., k. 210 ; tamże, M. Vicaire do A. de Monplanet, 15 VII 1922 r., k. 219.

100 AD, PL 1918-1940, 220, Note pour monsieur le Président de conseil, Paris, 17 VII 1922 r., k. 215v.

101 CAÉF, DT PL 1919-1939, B 31.942, A. de Monplanet do Ch. de Lasteyrie, 25 VIII 1922 r., bpag. 
Kłopoty wynikajace $\mathrm{z}$ tych zmian - wobec ślamazarności całego procesu - jawią się jako na poły humorystyczne. Wedle sprawozdania Olszewicza propozycje poprawek do projektu statutu własnoręcznie wprowadził premier Poincaré, który jednak, wobec innych obowiązków, nie miał następnie czasu rozmawiać na ich temat z polskimi przedstawicielami. Z kolei francuscy urzędnicy nie wyobrażali sobie działań sprzecznych z intencjami premiera. Kiedy sprawa z Korfantym sama się rozwiązała, Olszewicz ponownie przyjechał do Paryża, by ustalić takie brzmienie statutu, które - wedle pracowników Quai d’Orsay odpowiadałoby intencji ręcznych poprawek Poincarégo, nie uchybiając jednocześnie polskim celom (m.in. pozostawieniu układu z grudnia 1921 r. w tajemnicy ${ }^{102}$ ). Francuzi byli w negocjacjach gotowi przychylić się do polskiego punktu widzenia, mieli już bowiem wyznaczoną datę wyjazdu do Katowic w celu utworzenia banku. Ostatecznie rozwiązania były więc korzystne dla Polaków, nie wpływając w istotny sposób na zasady funkcjonowania banku ${ }^{103}$.

W obecności przedstawicieli Francji 8 VIII 1922 r. Bank Ślaski SA w Katowicach został formalnie utworzony, a Korfanty telegraficznie podziękował Albertowi de Monplanet za pomoc ${ }^{104}$. Tego samego dnia grupa francuska przelała swoją część kapitału zakładowego, a 14 sierpnia francuskie Ministerstwo Finansów przekazało polskiemu rządowi pożyczkę odpowiadająca polskiemu udziałowi ${ }^{105}$. Pożyczka została udzielona na zasadach przewidzianych we wspomnianej konwencji Klotz-Olszowski. W chwili przekazania jej stronie polskiej $115 \mathrm{mln}$ marek niemieckich miało wartość ok. 2,4 mln franków. Jej oprocentowanie wynosiło 5\%, spłat dokonywano sukcesywnie z zysków Skarbofermu. Pierwotnie ich zakończenie przewidziano do końca 1929 r., w rzeczywistości ostatnia spłata została dokonana już 8 II 1927 r. ${ }^{106}$

102 Co było zresztą sprzeczne z interesami Francuzów, którzy woleli głośno mówić o układzie jako o „manifestacji siły politycznej w kraju, w którym wpływy gospodarcze niemieckie pozostają dominujące”, za: tamże, Notatka dla E. de Peretti de la Rocca, 29 VII 1922 r., k. 224v.

103 Szczegółowe omówienie negocjacji zob. Z. Landau, J. Tomaszewski, dz. cyt., 42, s. $131-136$.

104 AD, PL 1918-1940, 220, A. de Monplanet do R. Poincarégo, Paris, 9 VIII 1922 r., k. 230-230v.

105 Tamże, Ch. de Lasteyrie do M. Zamoyskiego, 2 IX 1922 r., k. 239; wedle informacji z podsumowania sprawy w dokumentach Ministerstwa Finansów pożyczka została udzielona rok później, ale jest to zapewne omyłka kopisty; CAÉF, DT PL 1919-1939, B 31.942, Pologne II. Participation française à des entreprises polonaises, b.d., bpag.

106 CAÉF, DT PL 1919-1939, B 31.942, Pologne II. Participation française à des entreprises polonaises, b.d., bpag. 
Pytanie, co stało się z akcjami. Papiery o wartości $10 \mathrm{mln}$ złotych, należące formalnie do polskiej strony, przeją zapewne Skarboferm. Czy rząd polski przekazał jednak pozostałe akcje poszczególnym bankom (zob. załącznik 1)? We francuskiej notatce z $1931 \mathrm{r}$. mowa jest o przekazaniu akcji, a następnie odkupieniu ich przez władze centralne ${ }^{107}$. Ze wspomnień Wacława Konderskiego wynika, że całość polskich akcji trafiła do Polskiego Banku Krajowego, a następnie do BGK w ramach akcji wyzbywania się przez Skarb Państwa z „rozmaitych bezwartościowych, a kłopotliwych pozycji”108. Podobne stwierdzenia znaleźć można u Wojciecha Roszkowskiego, który pisał, że polski akcjonariat stanowiły „największe banki z Bankiem Handlowym na czele oraz rząd polski za pośrednictwem Polskiego Banku Krajowego"109. Ponieważ Polski Bank Krajowy istniał do 1924 r., dawało to dość niewielki margines czasowy na przekazanie akcji do banków prywatnych, a następnie przejęcie ich przez państwo ${ }^{110}$; z pewnością w 1925 r. całość polskich akcji znajdowała się w rękach BGK ${ }^{111}$.

Watpliwości co do precyzji sformułowań Konderskiego budzi też jego informacja o późnym przekazaniu akcji do spółek francuskich (przyjęta następnie $\mathrm{w}$ polskiej historiografii ${ }^{112}$ ), która stoi w sprzeczności z materiałem archiwalnym. Francuskie firmy od razu bowiem sfinansowały swój udział, zgodnie z wcześniejszymi ustaleniami. Jak pisali Józef Popkiewicz i Franciszek Ryszka: „Akcjonariuszami Banku Ślaskiego były [...] poważne francuskie domy bankowe: Banque de Paris et des Pays-Bas, Société Générale, Banque d'Alsace, Banque de Mulhouse, oraz towarzystwa przemysłowe: Société des Houillères i Société des Forges"113. Jednak tezy tych autorów o wpływie Niemców na działalność spółki ${ }^{114}$ nie znajduja potwierdzenia.

${ }_{107}$ AD, PL 1918-1940, 370, Note pour l'Ambassadeur, secrétaire général, 14 III 1931 r., k. 19.

108 W. Konderski, dz. cyt., s. 70.

${ }^{109}$ W. Roszkowski, Ksztattowanie sie podstaw polskiej gospodarki państwowej w przemyśle i bankowości w latach 1918-1924, Warszawa 1982, s. 378.

${ }_{110}$ Tak miało się to odbyć według Banque de Silésie SA, „Messager Polonais”, wyd. specjalne „La Haute-Silésie Polonaise”, X 1928, s. 41.

${ }_{111}$ AD, PL 1918-1940, 221, Banque de Silésie. Rapport au Président du conseil, Ministre des Affaires étrangères sur l'augmentation de capital, 31 I 1925 r., k. 126.

112 W. Morawski, Bank Ślqski SA - Banque de Silésie SA, „Gazeta Bankowa” 1989, nr 41, s. 12 .

113 J. Popkiewicz, F. Ryszka, Przemyst ciężki Górnego Ślaska w gospodarce Polski międzywojennej: 1922-1939. Studium historyczno-gospodarcze, Opole-Wrocław 1959, s. 108.

114 Tamże. 
Bank rozpoczął działalność w trudniejszych warunkach niż przewidywano. Największym problemem była postępująca inflacja marki niemieckiej. W chwili przekazania przez Francuzów pożyczki Polakom wartość kapitału zakładowego wynosiła równowartość $5 \mathrm{mln}$ franków ${ }^{115}$. W ciagu czterech miesięcy od założenia kapitał Banku Śląskiego stracił $90 \%$ wartości, co powodowało, że po poniesieniu przezeń kosztów początkowych trudno było o normalną działalność bankową ${ }^{116}$. Francuzi narzekali ponadto, że z powodu polskiej opieszałości bank rozpoczął działalność dopiero w październiku 1922 r. Jego pozycja w systemie polskiej bankowości państwowej okazała się słaba. Francuzi liczyli na rolę Banku Śląskiego jako przedstawiciela PKKP na Górnym Śląsku, gwarantowaną w porozumieniu z 29 XII 1921 r., dzięki czemu miałby on dodatkowe źródła dochodów z obsługi przelewów i przekazów na Górny Ślask, przechowywania depozytów Skarbu Ślaskiego, potencjalnie również kolei ${ }^{117}$.

Faktycznie jednak już w momencie podpisania porozumienia w 1921 r. projektowany kapitał banku był zbyt mały, aby zapewnić odpowiednią wartość kredytów dla Górnego Śląska ${ }^{118}$. Z czasem pozycja banku uległa dalszemu osłabieniu. Spadek wartości marki niemieckiej spowodował, że na terenie Górnego Śląska wprowadzono markę polską jako równorzędną walutę, co uczyniło Bank Ślasski zależnym od pomocy PKKP. Co więcej, Kasa nigdy nie uczyniła banku swoim reprezentantem. Wywołało to serię francuskich interwencji dyplomatycznych, ponaglanych przez listy władz banku do MAÉ. Po długich rozmowach polskie władze jednoznacznie stwierdziły, że artykuł porozumienia z grudnia 1921 r. o przedstawicielstwie PKKP jest „niemożliwy do wprowadzenia"119. Argumentowano też, że bank sam się zrzekł tego prawa w okresie inflacji, prosząc o dodatkową linię kredytowa z Kasy, a nowa sytuacja na Górnym Śląsku czyniła sprawę niebyłą ${ }^{120}$. Polska pozycję wzmocniło utworzenie Banku Polskiego i wprowadzenie także na Ślasku złotego na początku $1924 \mathrm{r} .{ }^{121}$

To ważny moment w rozwoju stosunków polsko-francuskich. Strona francuska z pewnością miała rację - porozumienie z grudnia $1921 \mathrm{r}$.

115 CAÉF, DT PL 1919-1939, B 31.942, Banque Franco-Polonaise, b.d., bpag.

116 Tamże, Notatka o Banku Ślaskim, 10 XI 1922 r., bpag.

117 AD, PL 1918-1940, 220, H.A. de Panafieu do R. Poincarégo, 14 XII 1922 r., k. 245v.

118 G.-H. Soutou, dz. cyt., s. 113.

119 AD, PL 1918-1940, 221, H.A. de Panafieu do MAÉ, 5 XI 1923 r., k. 53.

120 Tamże, H. Thélier, do Ch. Lasteyrie, 30 V 1923 r., k. 16-16b; tamże, R. Dmowski do [H.A. de Panafieu], 13 XII 1923 r., k. 72-73b; G.-H. Soutou, dz. cyt., s. 114.

${ }^{121}$ AD, PL 1918-1940, 221, H.A. de Panafieu do R. Poincarégo, 16 I 1924 r., k. 91v. 
było jednoznaczne i czyniło Bank Ślaski przedstawicielem wszelkich polskich banków państwowych, a nie jedynie PKKP (choć w umowach nie precyzowano, co to przedstawicielstwo mogłoby znaczyć). Tymczasem Polacy ignorowali argumenty Francuzów ${ }^{122}$, świadomie prowadząc do marginalizacji Banku Śląskiego. Niezależnie nawet od Banku Polskiego, Bank Gospodarstwa Krajowego - bank państwowy - otworzył oddział w Katowicach. Można się zastanawiać, jaki wpływ na te decyzje miało późne otwarcie Banku Ślaskiego, wynikajace z inercji decyzji politycznych ${ }^{123}$.

Polityczny rodowód banku ujawnił też dalsze problemy. Nadmiernie rozbudowana Rada Nadzorcza, licząca 24 członków podzielonych między Polskę a Francję, była mało sterowna, a podejmowanie decyzji wysoce kłopotliwe wobec powolnego kursowania poczty. Z kolei konieczność równego podziału akcji między stronę polską i francuską wyjątkowo utrudniało zwiększenie kapitału akcyjnego, faktycznie, wobec struktury własności akcji, uzależniając je od decyzji Polskiego Banku Krajowego, a następnie $\mathrm{BGK}^{124}$.

\section{Strony negocjacji i ich cele}

Aby lepiej zrozumieć opisany przebieg negocjacji, należy zastanowić się nad tym, kto we Francji i w Polsce był zainteresowany utworzeniem Banku Ślaskiego, a także jakie cele przyświecały obydwu stronom.

Francuscy negocjatorzy nie tworzyli spójnego frontu. Objawiało się to na różne sposoby. Po pierwsze, istniały dwie wyraźne grupy interesu o niespójnych celach: rząd, zorientowany bardziej na osiaganie celów politycznych, oraz przedstawiciele francuskich sfer finansowych, zainteresowani gwarancjami zysku w przedsięwzięciach w Polsce. Po drugie, w negocjacjach z Polakami rząd francuski również prezentował niespójne stanowisko: ujawniły się różnice stanowisk między resortami spraw zagranicznych i finansów.

O ile pierwsza ze sprzeczności istotnie występowała, druga należy rozumieć głównie jako taktykę negocjacyjną stosowaną przez Francuzów. Jakkolwiek w kilku momentach poglądy urzędników tych resortów istotnie się różniły, to dokumenty archiwalne potwierdzaja zgodność i współpracę obydwu ministerstw, zwłaszcza w późniejszych

122 G.-H. Soutou, dz. cyt., s. 114-115.

${ }^{123}$ AD, PL 1918-1940, 220, M. Vicaire do A. de Monplanet, 15 VII 1922 r., k. 218-220.

124 Tamże, H.A. de Panafieu do R. Poincarégo, 14 XII 1922 r., k. 245-247v. 
negocjacjach. Sugerowanie różnicy zdań umożliwiało żądanie od Polaków większych ustępstw.

Przy okazji dyskusji związanych ze śląskim oddziałem Banku Francusko-Polskiego w Paryżu ujawniło się jeszcze jedno pole konfliktów. Joseph Noulens skarżył się Laroche'owi, że generał Le Rond świadomie opóźnia czynności prowadzące do powstania oddziału banku, aby utworzyć „swój” Bank Górnoślaski ${ }^{125}$. Konflikt ten wskazuje przede wszystkim na kolejną formę niechęci prywatnego kapitału francuskiego wobec rządowego projektu oraz próbę przejęcia inicjatywy przez środowisko Banku Francusko-Polskiego i Izby Handlowej Francusko-Polskiej, której prezesem również był Noulens.

W przypadku strony polskiej sytuacja jest mniej skomplikowana. Początkowo negocjacje prowadzone były tylko przez Artura Benisa, który w przypadku szczególnie daleko idących żądań francuskich musiał konsultować się z Warszawa. W późniejszych miesiącach, po zakończeniu bezpośredniego zaangażowania Benisa, sprawa Banku Ślaskiego prowadzona była zwykłymi drogami dyplomatycznymi przez kontakty posłów obu państw - Maurycego Zamoyskiego w Paryżu i Hectora André de Panafieu $\mathrm{w}$ Warszawie $-\mathrm{z}$ ministerstwami, a także bezpośrednio w negocjacjach przez Wacława Olszewicza.

Ze zbadanych dokumentów nie wynika, by w polskim obozie istniały wyraźne różnice zdań, nawet jeśli Benisowi zdarzało się sugerować coś takiego w negocjacjach, aby wzmocnić swoja pozycję. Wątpliwości budzi jednak kwestia zaangażowania prywatnych instytucji $\mathrm{w}$ finansowanie ślasskiej inwestycji. Z przywoływanych materiałów Banku Handlowego w Warszawie wynika, że jego władze czuły się zobligowane wobec rządu obietnica uczestnictwa w Banku Ślaskim, choć jednocześnie widziały finansowy sens współpracy z Niemcami.

Jakie cele przyświecały obydwu stronom? W przypadku Francji uderza chęć wykorzystania banku do przejęcia kontroli nad gospodarka Górnego Ślaska, a przez to, jak pisano, całej Polski. Wydaje się, że kontrola ta miała opierać się początkowo na pełnieniu przez bank funkcji namiastki banku centralnego i „regulatora kredytu” na terenie województwa ${ }^{126}$. Z korespondencji wynika, że jakkolwiek był to najszerzej zakrojony z celów, Francuzi w zmienionej sytuacji byli jednak gotowi szybko $\mathrm{z}$ niego zrezygnować ${ }^{127}$. W drugiej kolejności kontrola nad gospodarka Ślaska miała wynikać z uczestnictwa banku w procesie przejmowania

125 Tamże, Notatka MAÉ, 25 II 1921 r., k. 143-143v.

126 Tamże, H.A. de Panafieu do R. Poincarégo, 14 XII 1922 r., k. 246.

${ }^{127}$ G.-H. Soutou, dz. cyt., s. 114. 
niemieckich przedsiębiorstw, a gdy to również zawiodło, miał on ułatwiać inne francuskie inwestycje. Dla francuskiego Ministerstwa Finansów szczególnie istotny był tu Skarboferm ${ }^{128}$. Hector André de Panafieu jeszcze w grudniu 1922 r. pisał, że do banku docierały „ciekawe propozycje, zwłaszcza związane z utworzeniem lub rozwojem firm na polskim Ślasku. Te z przedsiębiorstw, gdzie jego wpływ zastapiłby wpływy niemieckie, nie tylko zapewniają udział naszych kapitałów, ale jednocześnie gwarantują sprzedaż naszych produktów i surowców w Ślasku, również niemieckim. Bank Ślaski jest zatem agentem wyznaczonym dla umieszczania naszych kapitałów na Ślasku"129. Najszerszym i najtrwalszym francuskim celem było zmniejszanie wpływu niemieckiego kapitału na ślaskie finanse oraz niedopuszczenie kapitału z innych krajów na Górny Ślask.

Okazuje się zatem, że władze francuskie nie miały jasno sprecyzowanego gospodarczego celu stworzenia Banku Ślaskiego, a główne argumenty przemawiające za zaangażowaniem się w tę inwestycję miały charakter polityczny. Konkluzja ta jest spójna z tezą o niewielkiej wiedzy francuskich dyplomatów na tematy gospodarcze, nie tylko zreszta polskie ${ }^{130}$. Decydując się na popieranie inwestycji w Polsce, Quai d'Orsay nie miało wiedzy na temat wielkości tego rynku. W dokumentach wskazywano na duże znaczenie Ślaska i istotny potencjał gospodarczy nowego państwa. Wydaje się, że Francuzi poważnie ów potencjał przeszacowali.

Z kolei zarządzającym francuskimi bankami prywatnymi inwestycja w Bank Ślaski nigdy nie wydawała się korzystna - i zawsze sprawiała wrażenie raczej elementu rozgrywek politycznych ${ }^{131}$. Celem tych banków było bezpieczne ulokowanie posiadanych zasobów, a inwestowanie na nieznanym terenie, który mógł zmienić przynależność państwowa, nie wydawało się bezpieczne. Stąd też trudności w zebraniu inwestorów oraz naleganie przez nich na gwarancje ze strony polskiego rządu. Ostatecznie to banki francuskie, zmuszone do działania przez rząd w Paryżu, straciły na inwestycji w Bank Śląski najwięcej.

Prezes Maxime Vicaire miał szczególnie ambitną wizję działalności przedsiębiorstwa. W liście do MF z sierpnia $1922 \mathrm{r}$. wskazywał jego rolę „w autonomicznej prowincji śląskiej jako bliska granej przez Bank Państwa", a stanowisko dyrektora oraz działalność reprezentanta Grupy Przemysłowców Francuskich w Polsce była dla niego podstawą do

128 CAÉF, DT PL 1919-1939, B 31.942, Ch. de Lasteyrie do Groupement des Houillères sinistrées du Nord et du Pas-de-Calais, 14 II 1921 r., bpag.

129 AD, PL 1918-1940, 220, H.A. de Panafieu do R. Poincarégo, 14 XII 1922 r., k. 246v.

130 J.-B. Duroselle, Politique étrangère de la France: la décadence, 1932-1939, Paris 1983, s. 15-19.

131 G.-H. Soutou, dz. cyt., s. 111. 
wnioskowania o udzielenie mu paszportu dyplomatycznego ${ }^{132}$. O poczatkowym traktowaniu przez Francuzów Banku Ślaskiego jako quasi-państwowego świadczą też próby zdobycia mieszkań dla jego pracowników na zasadach obowiazujących urzędników państwowych. Rozbiły się one o postawę katowickiego magistratu, którego pracownicy jednoznacznie stwierdzili, że Bank Śląski nie był przedsiębiorstwem państwowym, a jego pracownikom nie należały się specjalne przywileje ${ }^{133}$.

Trudniej na podstawie przebadanych dokumentów prześledzić cele polskich negocjatorów. Z pewnościa jednak Bank Ślaski został początkowo pomyślany jako forma „łapówki” dla Francuzów - oddanie im kolejnego przywileju, który zachęciłby ich do zaangażowania się na Górnym Ślasku. Przynętą były potencjalne zyski i specjalne traktowanie, na które bank miał liczyć. Ten cel przestał być jednak istotny po podziale Górnego Ślaska, a mimo to Polacy wciąż byli zainteresowani stworzeniem banku. Benis wspominał w sprawozdaniu złożonym na tajnym posiedzeniu Rady Ministrów, że bank „pomyślany był pierwotnie jako koncesja dla kapitału francuskiego. Wkrótce atoli role się zamieniły, gdyż bank stał się potrzebnym dla nas, podczas gdy bankowość francuska zachowywała się wobec niego obojętnie i z nieżyczliwym chłodem"134. Prawdopodobnie to z tego cytatu Mylène Mihout-Natar wysnuła wniosek, że Polacy byli znacznie bardziej zainteresowani stworzeniem banku ${ }^{135}$.

Dlaczego był on Polakom potrzebny? Jak pisał we wspomnieniach Wacław Konderski, obliczony „był na stworzenie na wszelki wypadek podstawy dla penetracji na teren Ślaska” ${ }^{136}$. Innymi słowy chodziło o zbliżony do francuskiego cel ekspansji kapitałowej na Ślasku - ułatwienie przejmowania firm na terytorium przyszłego polskiego państwa z wykorzystaniem francuskiego kapitału, a także ich obsługę finansowa. W węższej formie, o której wspominał w czasie negocjacji Benis, działalność banku miała się sprowadzać do obsługi Skarbofermu i innych podobnych inicjatyw. Udzielenie Francuzom przywilejów miało na celu wykorzystanie zainwestowanych przez nich marek niemieckich do finansowania polskiej działalności na Górnym Śląsku. Węższa interpretacja oraz istnienie Banku Francusko-Polskiego

${ }^{132}$ Vicaire oferował $\mathrm{w}$ zamian rolę głównego informatora rządu francuskiego o sytuacji Górnego Śląsk. Władze francuskie były zainteresowane korzystaniem z jego informacji, nie udzieliły mu jednak paszportu; CAÉF, DT PL 1919-1939, B 31.942, M. Vicaire do P. Chaslesa, 17 VIII 1922 r., bpag.; tamże, R. Poincaré do Ch. de Lasteyrie, 30 XI 1922 r., bpag.

${ }_{133}$ Tamże, Magistrat Katowic do W. Janyski, 20 XI 1922 r., bpag.

134 Z. Landau, J. Tomaszewski, dz. cyt., 34, s. 111.

135 M. Mihout-Natar, dz. cyt., s. 149.

136 W. Konderski, dz. cyt., s. 70. 
skłoniło zapewne Popkiewicza i Ryszkę do postawienia niesłusznej tezy, że celem powstania Banku Ślaskiego była „prawdopodobnie wyłączna obsługa górnośląskich przedsiębiorstw mieszanych (z udziałem kapitału francuskiego), gdy natomiast Bank Francusko-Polski miał szersze, ogólnokrajowe zadania"137.

Na przełomie 1921 i 1922 r. Polacy starali się dodatkowo wykorzystać obietnicę stworzenia banku jako argument w negocjacjach z Niemcami. Ujawnił się przy tym ciekawy mechanizm negocjacyjny: Benis mógł tę zewnętrzną słabość Polaków wobec Niemców wykorzystać jako argument w rozmowach z Francja - i taktyka ta przyniosła efekty ${ }^{138}$. W tym czasie w dokumentach francuskich widać wzmożone poszukiwanie rozwiazań, które pozwoliłyby na utworzenie banku ${ }^{139}$.

Z dokumentów nie wynika, czy Polacy byli istotnie zainteresowani funkcjonowaniem Banku Ślasskiego jako przedstawiciela PKKP, czy też przyjmowali dotyczące tego zapisy umowy jako cenę konieczną dla pozyskania francuskiej współpracy. Nawet jednak jeśli w 1921 czy 1922 r. liczyli na wykorzystanie Banku Ślaskiego jako czynnika zapewniającego ciagłość obiegu pieniężnego na Górnym Śląsku, to inflacja marki niemieckiej szybko odsunęła te pomysły na dalszy plan. Znaczenie musiały mieć też zapisy konwencji polsko-niemieckiej z maja $1922 \mathrm{r}$. Wydaje się, że celem polskich władz stało się wówczas odsunięcie Banku Śląskiego od wpływu na śląska politykę. Tak rozumieć można konsekwentne blokowanie żądań banku o włączenie go do działalności PKKP, a prawdopodobnie też przejęcie akcji przez Polski Bank Krajowy.

\section{Zakończenie}

Georges-Henri Soutou, który analizował przytoczone tu francuskie dokumenty, za mierne wyniki działalności Banku Ślaskiego winił głównie powściagliwość i słabość banków prywatnych, które nie były zainteresowane realizacja planu MAÉ ${ }^{140}$. Wpisuje się to w jego szerszą koncepcję „imperializmu biednych”"

137 J. Popkiewicz, F. Ryszka, dz. cyt., s. 108.

138 AD, PL 1918-1940, 220, A. Briand do P. Doumera, 18 XI 1921 r., k. 76-77.

139 CAÉF, DT PL 1919-1939, B 31.942, J. Parmentier, Rapport au ministre sur la création d'une banque franco-polonaise en Haute-Silésie, [1922 r.], bpag.; tamże, Ch. de Lasteyrie do Groupement des houillères sinistrées du Nord et du Pas-de-Calais, 14 II 1922 r., bpag.

140 G.-H. Soutou, dz. cyt., s. 114-115.

141 Szerzej na ten temat zob. J. Łazor, Kapitał francuski w Polsce międzywojennej. Stan badań i postulaty badawcze, „UR Journal of Humanities and Social Sciences” 4, 2019, nr 1 (10), s. 29-52. 
Z lektury materiałów archiwalnych wyłania się jednak nieco inna historia Banku Ślaskiego. Jego konstrukcja wynikała z konkretnej sytuacji politycznej w momencie powstania, stając się następnie przeszkodą $\mathrm{w}$ funkcjonowaniu. Co ważniejsze, za niepowodzeniem banku z perspektywy francuskiej stał raczej brak realistycznych celów gospodarczych oraz rozdźwięk między najważniejszymi dostawcami kapitału a głównymi motorami działalności. Niewątpliwie znaczenie miał też fakt, że planowane przejmowanie prywatnych przedsiębiorstw niemieckich, w których uczestniczyć miał bank, zakończyło się niepowodzeniem ${ }^{142}$.

Z perspektywy polskich władz negocjacje w sprawie Banku Ślaskiego okazały się zadziwiająco skuteczne. Udało się - przy braku jakiegokolwiek finansowania ze strony państwa - pozyskać istotny kredyt dzięki powiązaniu nowego projektu z inną francusko-polską aktywnością na Górnym Ślasku. Gdyby marka pozostała silna waluta, Polacy uzyskaliby w Banku Ślaskim wsparcie dla swojej polityki w województwie za cenę przejściowej utraty części suwerenności gospodarczej (podobnie jak w przypadku Skarbofermu). Spadek wartości marki niemieckiej sprawił, że pierwotna francuska pożyczka nie stanowiła obciążenia dla polskiego Skarbu, a umiejętna polityka zagraniczna odsunęła zagrożenie dla suwerenności.

To, że Polacy mogli zignorować zapisy porozumienia z $1921 \mathrm{r}$. wynikało prawdopodobnie z faktu, iż Francuzom udało się osiagnąć swój cel polityczny - niedopuszczenie innego kapitału na Górny Ślask - i nie byli zainteresowani dalszym zajmowaniem się Bankiem Śląskim. Jak pisał pod koniec 1923 r. Hector André de Panafieu: „Rząd francuski, który był za jego [Banku Ślaskiego - J.Ł.] utworzeniem, musi być głównym zainteresowanym jego sukcesem"143. Wobec braku tego zainteresowania bankpozostawiony sam sobie i dodatkowo osłabiony przez kryzys bankowy 1925 r. ${ }^{144}$ - wykazywał mała aktywność. W konsekwencji w latach $1931-$ -1932 został zlikwidowany. Inicjatywa traktowana w pewnym momencie jako „broń dyplomatyczna” okazała się gospodarczym niewypałem.

W tekście skoncentrowałem się na procesie powstania Banku Ślaskiego SA. Z lektury dokumentów wyłaniają się cztery zagadnienia, które wymagaja głębszych badań: po pierwsze, dalsze losy banku, zwłaszcza kolejne próby zwiększania kapitału; po drugie, szersze

${ }^{142}$ G.-H., Soutou, Les mines de Silésie et la rivalité franco-allemande, 1920-1923. Arme économique ou bonne affaire?, „Relations Internationales” 1974, t. 1, nr 1, s. $135-154$.

143 AD, PL 1918-1940, 220, H.A. de Panafieu do R. Poincarégo, 14 XII 1922 r., k. $245-247 \mathrm{v}$.

${ }^{144}$ W. Morawski, Bank Ślaski SA... 
zagadnienie francuskich inwestycji w polskim sektorze bankowym, szczególnie interakcje między poszczególnymi spółkami; po trzecie, reinterpretacja misji Artura Benisa, uwzględniająca wnioski z niniejszych badań; po czwarte wreszcie, porównanie negocjacji, które doprowadziły do powstania Banku Ślaskiego, ze sposobem organizacji innych inwestycji francuskich w Polsce ${ }^{145}$.

Załącznik 1. Udziały francuskich akcjonariuszy Banku Śląskiego SA według francuskiej listy z 28 VI 1922 r. (w mln marek niemieckich)

\begin{tabular}{|c|c|}
\hline Nazwa firmy & Wartość udziału \\
\hline $\begin{array}{l}\text { Banque Nationale de Crédit oraz } \\
\text { Comptoir d'Escompte de Mulhouse }\end{array}$ & 15 \\
\hline Comité des Forges & 15 \\
\hline Comité des Houillères & 15 \\
\hline Banque de Paris et des Pays-Bas & 10 \\
\hline Crédit Industriel et Commercial & 10 \\
\hline Banque Française pour le Commerce et l'Industrie & 6 \\
\hline Banque d'Alsace et de Lorraine & 5 \\
\hline Banque de la Seine & 5 \\
\hline Banque de Mulhouse & 5 \\
\hline Société Alsacienne de Crédit Industriel et Commercial & 5 \\
\hline Société Générale Alsacienne de Banque & 5 \\
\hline Société Nancéienne de Crédit Industriel et de Dépôts & 4 \\
\hline Henri Thélier (członek zarządu Crédit Industriel et Commercial) & 3,8 \\
\hline SA des Mines de Czeladź & 3 \\
\hline Société Française des Pétroles Premier & 2 \\
\hline Banque des Pays du Nord & 1 \\
\hline Banque du Rhin & 1 \\
\hline Charbonnage, Mines et Usines de Sosnowice & 1 \\
\hline Inni & 16,2 \\
\hline Łącznie & 125 \\
\hline
\end{tabular}

Źródło: CAÉF, DT PL 1919-1939, B 31.942, A. de Monplanet do R. Poincarégo, 28 VI 1922 r., Załącznik „Banque de Haute-Silésie”, bpag.; Ch. Laforest, La stratégie française et la Pologne (1919-1939). Aspects économiques et implications politiques, Paris 2001, mps pracy doktorskiej, Université Paris 1 Panthéon-Sorbonne, s. 286.

145 Por. J. Łazor, Świstek papieru. Pierwsza francusko-polska koncesja kolejowa $w$ Drugiej Rzeczypospolitej, w przyg. do druku. 
Załącznik 2. Planowane udziały polskich akcjonariuszy Banku Śląskiego SA według francuskiej listy z 28 VI 1922 r. (w mln marek niemieckich)

\begin{tabular}{|c|c|}
\hline Nazwa firmy & Wartość udziału \\
\hline Bank Handlowy w Warszawie & 16 \\
\hline Polski Bank Przemysłowy we Lwowie & 16 \\
\hline Polski Bank Krajowy & 16 \\
\hline Bank Zwiąku Spółek Zarobkowych SA w Poznaniu & 16 \\
\hline Bank Towarzystw Spółdzielczych SA w Warszawie & 4 \\
\hline Bank Zjednoczonych Ziem Polskich SA w Warszawie & 4 \\
\hline Bank Zachodni SA w Warszawie & 4 \\
\hline Bank Dyskontowy Warszawski SA & 4 \\
\hline Bank Ziemiański SA w Warszawie & 3 \\
\hline Bank Kredytowy w Warszawie SA & 3 \\
\hline Bank Przemysłowy Warszawski SA & 2 \\
\hline Bank Przemysłowców Polskich SA w Warszawie & 2 \\
\hline Bank Małopolski SA w Krakowie & 4 \\
\hline Ziemski Bank Kredytowy SA we Lwowie & 3 \\
\hline Akcyjny Bank Hipoteczny SA we Lwowie & 2 \\
\hline Akcyjny Bank Zwiąkowy SA we Lwowie & 2 \\
\hline Polski Bank Handlowy SA w Poznaniu & 4 \\
\hline Bank Przemysłowców w Poznaniu & 4 \\
\hline Bank Handlowy w Łodzi SA & 2 \\
\hline Bank Kupiecki Łódzki SA w Warszawie & 2 \\
\hline Wileński Prywatny Bank Handlowy SA & 2 \\
\hline Skarboferm & 10 \\
\hline Łącznie & 125 \\
\hline
\end{tabular}

Źródło: CAÉF, DT PL 1919-1939, B 31.942, Lista polskich akcjonariuszy Banku Śląskiego, bpag.; AD, PL 1918-1940, 220, Banque de Silésie. Souscription de la part polonaise, k. 192.

\section{Bibliografia}

Bariéty J., Industriels allemands et industriels français à l'époque de la République de Weimar, „Revue d'Allemagne et des pays de langue allemande” 4, 1974, nr 2, s. 1-16.

Błahut K.J., Polsko-niemieckie stosunki gospodarcze w latach 1919-1939, Wrocław 1975.

Czernecki S., Bankowość polska na Górnym Ślasku, w: Dzieje pracy Górnego Ślaska 1922-1927, Lwów-Katowice 1927, s. 79-82. 
Duroselle J.-B., Politique étrangère de la France: la décadence, 1932-1939, Paris 1983.

Gassiorski A., Bank Handlowy w Warszawie S.A. Oddziat w Częstochowie 1897-1997. Historia oddziału banku na tle instytucji finansowych regionu, Częstochowa 1997.

Kukułka J., Francja a Polska po traktacie wersalskim: 1919-1922, Warszawa 1970.

Laforest Ch., La stratégie française et la Pologne (1919-1939). Aspects économiques et implications politiques, Paris 2001, mps pracy doktorskiej, Université Paris 1 Panthéon-Sorbonne.

Landau Z., Polskie zagraniczne pożyczki państwowe 1918-1926, Warszawa 1961.

Landau Z., Tomaszewski J., Misja prof. A. Benisa, „Teki Archiwalne” 6, 1959, s. 29-225.

Łazor J., Kapitat francuski $w$ Polsce międzywojennej. Stan badań i postulaty badawcze, „UR Journal of Humanities and Social Sciences” 4, 2019, nr 1 (10), s. 29-52.

Łazor J., Świstek papieru. Pierwsza francusko-polska koncesja kolejowa w Drugiej Rzeczypospolitej, w przyg. do druku.

Mihout-Natar M., L’intervention des capitaux français dans la Pologne de la Seconde République (1918-1939). Contribution à l’histoire de l’impérialisme économique français en Europe centrale, Lille 2002, mps pracy doktorskiej, Université Charles de Gaulle - Lille III.

Morawski W., Bank Ślaski SA - Banque de Silésie SA, „Gazeta Bankowa” 1989, nr 41, s. 12.

Morawski W., Bankowość prywatna w II Rzeczypospolitej, Warszawa 1996.

Morawski W., Słownik historyczny bankowości polskiej do 1939 roku, Warszawa 1998.

Popkiewicz J., Ryszka F., Przemyst ciężki Górnego Ślaska w gospodarce Polski międzywojennej: 1922-1939. Studium historyczno-gospodarcze, Opole-Wrocław 1959.

Roszkowski W., Ksztattowanie się podstaw polskiej gospodarki państwowej $w$ przemyśle $i$ bankowości $w$ latach 1918-1924, Warszawa 1982.

Ryszka F., Kulisy decyzji $w$ sprawie Ślaska w r. 1921, KH, t. 60, 1953, nr 1, s. $127-167$.

Soutou G.-H., Les mines de Silésie et la rivalité franco-allemande, 1920-1923. Arme économique ou bonne affaire?, „Relations Internationales” 1, 1974, nr 1 , s. $135-154$.

Soutou G.-H., La politique économique de la France en Pologne (1920-1924), „Revue historique” 251, 1974, nr 1, s. 85-116.

Szmidtke Z., „Skarboferm” 1922-1939: zwiazki polityki z gospodarka, Opole 2005.

Trąba M., Bankowość, w: Województwo ślaskie (1922-1939). Zarys monograficzny, red. F. Serafin, Katowice 1996, s. 365-390. 
Jerzy Łazor

"Diplomatic weapon of the highest caliber"? Creation of the Polish-French Bank Ślaski SA after World War I

(Summary)

Bank Ślaski SA [Silesian Bank SA] was founded in Katowice in August 1922 by virtue of a secret Polish-French convention signed in December 1921. The new bank was owned in half by French private companies and was in half financed by Poland via a loan granted by France (the Polish shares were eventually taken over by the state-owned Bank Gospodarstwa Krajowego [National Economy Bank]). The idea to found the bank originated from the Poles, who were seeking to spark French interest in the economy of Upper Silesia and thus secure support for the region's incorporation into Poland. The French negotiators, in turn, were trying to exploit their geopolitical leverage over Poland and force it to give the new bank powers which would effectively convert it into the central bank of Upper Silesia, including the right to issue currency. After the division of Upper Silesia, the creation of the bank was to equip Poles with a "diplomatic weapon" in negotiations with Germany. The reluctance of private investors from France to become involved in Polish business was one of the factors which delayed the establishment of the new institution, while the inflation of the German mark, which at the time was still the official currency in Silesia, undermined the financial foundations of the bank. In view of such a state of affairs, Poles put up a successful front against the French ambitions and did not fulfill the commitment of making Bank Ślaski the representative of Polska Krajowa Kasa Pożyczkowa [Polish Loan Bank] in the area of Upper Silesia.

Jerzy Lazor - dr, pracuje w Katedrze Historii Gospodarczej i Społecznej Szkoły Głównej Handlowej w Warszawie. Specjalizuje się w historii gospodarczej okresu międzywojennego, historii finansów i stosunków międzynarodowych. Stypendysta Imre Kertész Kolleg w Jenie. Autor m.in. monografii Brama na Bliski Wschód. Polsko-palestyńskie stosunki gospodarcze w okresie międzywojennym, Warszawa 2016 oraz edycji Moich wspomnień Stanisława Wojciechowskiego, Warszawa 2017.

Jerzy Lazor - dr, employee of the Department of Economic and Social History, SGH Warsaw School of Economics. He specialises in economic history of the interwar period, history of finances and international relations. Former fellow of the Imre Kertész Kolleg in Jena. His publications include the monograph Brama na Bliski Wschód. Polsko-palestyńskie stosunki gospodarcze w okresie międzywojennym (Warsaw, 2016) and an edition of Moje wspomnienia by Stanisław Wojciechowski (Warsaw, 2017).

E-mail: jlazor@sgh.waw.pl. 